ARCHIWA - KanCELARIE - ZBIORY

NR 1 (3)/2010

\author{
Waldemar ChORĄŻYCZEWSKI
}

\title{
Prywatne ARChiWa POlitycZne W Polsce XVI Wieku
}

Pamięci Ryszarda Marciniaka

\section{DeFiniCJA PRYWATNEgo ARCHIWUM POLITYCZNEgo}

7 [ermin „archiwum polityczne” pojawiał się już w literaturze naukowej. [ Tak została określona ta część spuścizny rękopiśmiennej Ignacego Jana Paderewskiego, która odzwierciedla jego działalność polityczną ${ }^{1}$. O archiwum politycznym mówił też parokrotnie w swojej rozprawie o Tomicianach Ryszard Marciniak. Pierwszy raz, gdy pisał o twórcach sylw szlacheckich, że zbierali skrzętnie teksty polityczne i „dołączali do swoich prywatnych ksiąg - archiwów politycznych, tzw. sylw”" Za drugim razem, porównując sytuację polską z węgierską w XVI wieku, skonstatował o możnych rodach węgierskich, że „posiadały własne archiwa polityczne, wśród których, prócz akt i listów, znajdowały się odpisy zbiorów praw, rękopiśmienne diariusze i kopie

Waldemar Chorążyczewski - Instytut Historii i Archiwistyki Uniwersytetu Mikołaja Kopernika w Toruniu, e-mail: wch@umk.pl. Zainteresowania badawcze: archiwistyka, dyplomatyka staropolska, historia XVI w., dzieje Kujaw w epoce nowożytnej, różne sposoby myślenia o przeszłości.

1 Archiwum polityczne Ignacego Jana Paderewskiego, t. 1-6, Wrocław-Warszawa 1973-2007.

2 R. Marciniak, Acta Tomiciana w kulturze politycznej Polski okresu odrodzenia, Warszawa-Poznań 1983, s. 138. 
korespondencji królewskiej”3. Jest też mowa o archiwum politycznym Mikołaja Spytka Ligęzy z XVII wieku

Pozwoliłem sobie termin ten doprecyzować przymiotnikiem „prywatny”. Chodzi mi bowiem o zjawisko gromadzenia i wykorzystywania akt politycznych przez osoby prywatne, chociaż w celu uczestniczenia przez nie w życiu publicznym. Przez pojęcie „prywatne archiwum polityczne” rozumiem zatem całość akt świadomie zgromadzoną przez osobę prywatną w związku z jej uczestnictwem w życiu politycznym, w celu wykorzystania w działalności publicznej jako źródło argumentacji oraz informacji o czynnikach i mechanizmach procesów politycznych.

Każde ze słów składających się na termin „prywatne archiwum polityczne” ma zasadnicze znaczenie. Mowa będzie o archiwach powstających w wyniku inicjatywy i na marginesie działalności publicznej osób prywatnych, nie zaś informatoriów istniejących przy kancelariach miejskich, kościelnych czy królewskiej. Całość materiałów politycznych zgromadzona w wyniku tych prywatnych działań musi mieć charakter archiwum - całości świadomie ukształtowanej, ale jednocześnie niebędącej wynikiem kolekcjonerstwa, pozostającej w związku z działalnością swych twórców, stanowiącej produkt uboczny tej ich aktywności, co jest cechą wszelkich akt. Informacja zawarta w analizowanych prywatnych archiwaliach musiała mieć wymiar polityczny - powinna: orientować w aktualnej sytuacji, poczynaniach znacznych osób i układzie sił w kraju, zarówno na dworze królewskim, jak i na prowincji; zaznajamiać z urządzeniem, zwyczajami i personaliami krajów obcych, zwłaszcza sąsiednich; śledzić stosunki międzynarodowe; dostarczać wzorców postępowania na każdym etapie procesu decyzyjnego; wyposażać w przykłady rozwiązań prawnopaństwowych przyjętych szczególnie w swym własnym kraju, na które można powołać się w argumentacji politycznej.

\section{Prywatne archiwa polityczne W PIERWSZEJ POŁOWIE XVI WIEKU}

Pierwsza połowa XVI wieku w dziedzinie gromadzenia i wykorzystania akt w działalności politycznej wykazuje wciąż wiele cech upodabniających ją do średniowiecza. Archiwów politycznych odnotowujemy niewiele. Grono ich twórców ma ściśle określony profil. Wciąż jeszcze aktualne jest wyzwanie polityczne stwarzane przez zakon krzyżacki w Prusach. Z tego względu dokumentacja stosunków polsko-krzyżackich z wieków XIII, XIV i XV, przy-

3 Tamże, s. 168-169.

${ }^{4}$ J. Wiśniewski, Archiwalia w bibliotekach i muzeach, Poznań 2000, s. 71. 
najmniej do roku 1525, nie traci na bieżącej wartości. Kolejne kodeksy z tą dokumentacją są tworzone lub odpisywane, jak ten Jerzego Myszkowskiego (ok. 1480-1543), zawierający akta ilustrujące stosunki polsko-krzyżackie od sprowadzenia zakonu na ziemię chełmińską do wojny trzynastoletniej (Biblioteka Czartoryskich, dalej cyt. B. Czart., rps sygn. 235).

Zjawisko gromadzenia akt do dziejów stosunków z Krzyżakami odegrało znaczną rolę w działalności biskupa warmińskiego Łukasza Watzenrodego, który jeszcze przed rokiem 1500 wypożyczył z kancelarii królewskiej kopiariusz dokumentów lub korespondencji (liber litterarum), zwrotu którego domagał się podkanclerzy Maciej Drzewicki. W liście datowanym z Włocławka 7 czerwca 1501 roku Krzesław Kurozwęcki, kanclerz wielki koronny, informował, że przesyła Łukaszowi akta dawniejszych sporów polsko-krzyżackich z czasów króla Władysława, nie wiadomo, czy Łokietka, czy Jagiełły ${ }^{5}$ W dziesięć lat później biskup warmiński został poproszony jednocześnie przez króla i precyzującego wymagania królewskie Drzewickiego o utworzenie tomu uzasadniającego prawa Polski do ziem pruskich, w tym zawierającego papieskie bulle i pisma, w celu przedstawienia ich w Rzymie. Bliskość śmierci Watzenrodego nie gwarantowała wykonania zamówienia ${ }^{6}$. Wiemy jednak, że w roku 1511 Mikołaj Kopernik przekazał wujowi przepisany dlań przez siebie traktat pokojowy polsko-krzyżacki zawarty w roku 1411 . Watzenrode przygotowywał się do rozmów z Krzyżakami, które miały odbyć się w Toruniu 13 grudnia 1511 roku?

Nową jakość w zagadnienia archiwów osobistych dyplomatów i posługiwania się przez nich dokumentacją aktową wniósł niewątpliwie Erazm Ciołek (1474-1522). Jako dyplomata przygotował dla siebie kopiariusz akt dyplomatycznych z okresu swoich pierwszych dwóch legacji do Rzymu - pierwszej od wielkiego księcia litewskiego Aleksandra w roku 1501, drugiej od tegoż jako króla polskiego w roku 1505. Prócz akt poselstw kopiarz zbierał także inne materiały godne pamięci, związane luźniej z poselstwami lub tylko z osobą Erazma Ciołka. W późniejszym czasie dodano również zbiór akt papieskich z lat 1507-1510 o odpustach jubileuszowych i krucjacie antytureckiej. Źródeł

5 Akta stanów Prus Królewskich, t. 3, cz. 2: (1498-1501), wyd. K. Górski, M. Biskup, Toruń 1963, nr 543.

6 I. Janosz-Biskupowa, Zainteresowania archiwalno-historyczne biskupów warmińskich w poczatkach XVI w., Acta Universitatis Nicolai Copernici, Historia 16, 1980, s. 90-91.

7 J. Obłąk, Mikołaja Kopernika Inwentarz dokumentów w skarbcu na zamku w Olsztynie roku pańskiego 1520 oraz inne zapisy archiwalne, Studia Warmińskie, t. 9, 1972, s. $15-16$. 
materiałów zawartych w kodeksie należy się doszukiwać w księgach kancelarii papieskiej oraz w oryginalnych aktach przechodzących przez ręce Ciołka, część też, jak bulle i listy papieskie z drugiej połowy XV wieku, uzyskał on najpewniej z archiwum koronnego w Krakowie. Ciołek włączył do księgi również dwie swoje własne mowy wygłoszone na konsystorzu publicznym oraz noty objaśniające swego autorstwa. Kopiariusz stanowił własność osobistą Ciołka. Nie był to zresztą jedyny kodeks aktowy będący w jego posiadaniu. Druga księga zawierała materiały poselstw Ciołka na sejm augsburski 1518 roku i z lat następnych do Rzymu ${ }^{8}$.

Osoba Erazma Ciołka stanowi dogodne przejście do obserwacji zjawiska specyficznego już dla wieku XVI, rozpoczynającego ciąg rozwojowy prowadzący do rozpowszechnienia się prywatnych archiwów politycznych w ostatniej ćwierci wieku. Chodzi tutaj o dokumentację gromadzoną przez kanclerzy w związku z ich działalnością urzędową, jednakże na osobisty użytek i traktowaną przez nich jak własność prywatna. Kancelaria królewska jako dostarczyciel akt politycznych funkcjonowała permanentnie. Poczet interesujących nas pieczętarzy rozpoczyna Jan Łaski (1456-1531). Warto zauważyć, że odznaczał się on skłonnością zarówno do pracy intelektualnej, jak i do dokumentowania różnych aspektów swojego życia i działalności. Oprócz listów i mów (jedną z nich zwyczajem humanistycznym ogłosił drukiem ${ }^{9}$ ) był autorem nieznanych dziś rozpraw o Rusinach, o dziejach Kościoła i z zakresu geografii. Na zlecenie prymasa Bernard Wapowski opublikował w roku 1515 w Rzymie zbiór wierszy opiewających zwycięstwo pod Orszą. Łaski interesował się kroniką Macieja Miechowity, a po jej ukazaniu się w roku 1519 przyczynił się do jej konfiskaty zwłaszcza z powodu niekorzystnego przedstawienia rządów Aleksandra Jagiellończyka. W wydaniu poprawionym niektóre fragmenty dopisał sam. Wiemy też, że posiadał rękopis kroniki Galla Anonima w odpisie z XIV wieku. Zainicjował nie tylko spisanie praw Królestwa w tak zwanym Statucie Łaskiego, ale także kodeksu praw dla miast i wsi. Od roku 1495 do śmierci sumiennie notował w osobnym zeszycie swoje wierzytelności i długi. Do zeszytu tego wpisał też swój testament, wobec czego pod tą nazwą znany jest on dziś. Po objęciu archidiecezji gnieźnieńskiej doprowadził do spisania w latach 1511-1512 swoich miast i wsi wraz z płynącymi z nich dochodami. W ordynacji wydanej dla chłopów w dobrach arcybisku-

8 Kopiarz rzymski Erazma Ciotka z początku wieku XVI, oprac. S. Kutrzeba, J. Fijałek, Archiwum Komisji Historycznej PAU, seria 2, t. 1, Kraków 1923, s. 68-69.

9 J. L. Decjusz, Księga o czasach króla Zygmunta, wyd. T. Bieńkowski, Warszawa 1960, s. 72 . 
pich polecał prowadzić rejestr w celu zapisywania kar za niewywiązywanie się poddanych z powinności ${ }^{10}$.

Jan Łaski, zastępując kanclerza i podkanclerzego koronnych przy królu Aleksandrze w czasie jego wyjazdów na Litwę, zaprowadził specjalne księgi do swego osobistego użytku. Jednocześnie zlecił swemu współpracownikowi w kancelarii Erazmowi Ciołkowi sporządzenie kodeksu z aktami dawniejszymi, objaśniającymi sprawy bieżące. Jesienią 1503 roku pierwszy tom podręczny zapełnił się i zaprowadzono drugi, także do osobistego użytku Łaskiego. Wkrótce jednak Łaski został kanclerzem i stanęły przed nim otworem archiwalia państwowe. Zainteresowanie prywatnym kodeksem tym samym zmalało. Wpisywano do niego coraz mniej aktów, aż urwały się one w połowie 1505 roku. Raz jeszcze Łaski użył księgi w roku 1508, kiedy to towarzyszył królowi w wyprawie wschodniej. Wszystkie trzy tomy znajdowały się w ręku Łaskiego po jego odejściu z kancelarii w roku 1510, jednakże po śmierci ekskanclerza kancelaria królewska zainteresowała się nimi i wcieliła do Metryki Koronnej. Pierwszy tom zbiera akta z lat 1501-1504, drugi 1503-1505 i 1508, trzeci zaś akta dawniejsze spraw węgierskich, mołdawskich, litewskich, tureckich, mazowieckich, przywileje ziemskie, opis Szwecji z czasów wielkoksiążęcych Aleksandra - najwięcej jest materiałów z czasów Jana Olbrachta, inne sięgają nawet XIV wieku' ${ }^{11}$.

Podobnie jak Łaski, własne księgi kancelaryjne prowadził Maciej Drzewicki (1467-1535). Nie zaniedbywał on zajęć intelektualnych. Pozostawił po sobie autobiografię, rodowód Ciołków na Drzewicy, dziennik z lat 1499-1515 oraz opis wypadków gdańskich 1526 roku $^{12}$. Żadnej z tych prac Drzewicki jednak nie rozpowszechniał, powstawały one zresztą nieraz na marginesach ksiąg i książek używanych przez biskupa. W 1504 roku Maciej Drzewicki napisał przedmowę do dziełka Kallimacha $O$ usitowaniach Wenecji, aby podburzyć przeciwko Turcji Persów i Tatarów (De his, quae a Venetis tentata sunt Persis ac Tartaris contra Turcos movendis). Drzewicki przytacza tu pogląd przyjaciela Kallimacha Piotra z Bnina, biskupa włocławskiego, że historię powinni pisać ludzie, którzy zajmują się działalnością publiczną. Działalność ta bowiem to zasadniczy i właściwy podmiot historiografii. Tylko biorąc udział w sprawach publicznych, a nie studiując filozofów, wie się, co jest dla państwa dobre ${ }^{13}$.

10 Z. Kaczmarczyk, O kanclerzu Janie Easkim, Warszawa 1955, s. 23-26, 62, 68-70.

${ }^{11}$ Akta Aleksandra króla polskiego, wielkiego księcia litewskiego i t.d. (1501-1506), wyd. F. Papée, Kraków 1927, s. VIII-X.

${ }_{12}$ H. Rybus, Prymas Maciej Drzewicki: zarys biografii (1467-1535), Studia Theologica Varsaviensia, R. 2, 1964, nr 1-2, s. 82-93.

13 J. Domański, Z. Ogonowski, L. Szczucki, Zarys dziejów filozofii w Polsce. Wieki XIII-XVII, Warszawa 1989, s. 213-214. 
Trzeba jeszcze dodać cztery pisane ręką kanclerza kodeksy aktów publicznych oraz bogatą korespondencję. Otrzymamy w ten sposób portret osoby przywykłej do pracy umysłowej, obcującej na co dzień z książką, choć wolnej od potrzeby zabłyśnięcia na polu literackim.

Za kanclerstwa Macieja Drzewickiego sam kanclerz układał pisma w sprawach publicznych, jak o tym świadczą cztery księgi zapisane drobnym pismem Drzewickiego z mandatami i listami. Dopiero z tych konceptów kanclerskich były sporządzane czystopisy. Księgi Macieja Drzewickiego nie przynależały formalnie do Metryki Koronnej, stąd też kanclerz, odchodząc z urzędu, zabrał je, jako prywatne rejestry, ze sobą ${ }^{14}$. Pierwszy z rejestrów kancelarii koronnej Macieja Drzewickiego obejmuje listy, mandaty, instrukcje dyplomatyczne i inne akta z okresu od 10 czerwca 1510 do 19 lipca 1511 roku, pisane ręką samego Drzewickiego (B. Czart. 252 IV). Drugi z kodeksów zawiera analogiczne ekspedyty kancelarii koronnej z okresu od 3 lipca 1511 do 20 października 1512 roku, również pisane ręką niemal wyłącznie Drzewickiego (B. Czart. 253 IV). Rejestr wart jest szczególniejszej może uwagi ze względu na noty historyczno-memoriałowe umieszczone na wyklejkach, jak choćby zapiski o królu Jagielle i jego synach czy też o władcach krymskich. Trzeci z kodeksów obejmuje okres od 20 października 1512 do 13 stycznia 1514 roku (Archiwum Archidiecezjalne w Gnieźnie, Akta Konsystorskie, sygn. G VII, 16). Ostatni zaś obejmuje okres od 18 stycznia 1514 do 28 sierpnia 1516 roku, ponadto legacje i korespondencję dyplomatyczną z lat 1512-1514 oraz zbiór brewe papieskich z lat 1491-1514 (Biblioteka Jagiellońska, dalej cyt. BJ, rps sygn. 38).

Trzecim z kolei pieczętarzem interesującym nas ze względu na postępowanie z aktami swego urzędu był Piotr Tomicki (1464-1535). Traktował on je podobnie jak Łaski i Drzewicki, tyle że wydawał się okazywać o nie większą jeszcze troskę. Tomicki dbał o swoje akta, zarówno urzędowe, jak i prywatne, nie rozróżniając ich zresztą ${ }^{15}$. Około roku 1528 sformułowano z nich fascykuły grupujące tematycznie listy i akta. $\mathrm{Na}$ odwrociach niektórych aktów zaczęły się wówczas pojawiać noty o ich przynależności rzeczowej. Poszczególne jednostki aktowe dotyczyły na przykład spraw gdańskich, węgierskich, pruskich czy mazowieckich. Ryszard Marciniak domyśla się, że prace porządkowe wykonał Stanisław Górski ${ }^{16}$. Zachował się także prywatny ko-

14 R. Marciniak, dz. cyt., s. 41, 45.

15 W. Pociecha, W sprawie wydawnictwa Actów Tomicianów, Pamiętnik Biblioteki Kórnickiej, z. 3, 1939-1946, s. 24.

16 R. Marciniak, dz. cyt., s. 43-44. 
piariusz Piotra Tomickiego z lat [1518] 1523-1528 (Biblioteka Kórnicka, dalej cyt. BK, rps sygn. 228), pisany w dużej mierze jego ręką ${ }^{17}$.

Poprzez osobę Piotra Tomickiego docieramy do jego pisarza w kancelarii mniejszej Stanisława Górskiego (1497-1572), z którego imieniem wiąże się najciekawszy bodaj przypadek spożytkowania akt w działalności politycznej w XVI wieku. Acta Tomiciana pomyślane początkowo jako pomnik dla idealnego męża stanu, jakim miał być podkanclerzy Tomicki, stanowią punkt zwrotny w dziejach prywatnych archiwów politycznych w Polsce. Trzeba jednak pamiętać, że pierwsza połowa XVI wieku to dopiero kształtowanie się idei Tomicianów i zapoczątkowanie ledwie pierwszych prac redakcyjnych. Pracę nad spuścizną Tomickiego poprzedził Stanisław Górski zbieraniem Cricianów. Wiersze Andrzeja Krzyckiego mógł gromadzić Górski jeszcze za życia Tomickiego, korespondencję uzyskał do zbioru najpóźniej w końcu lat trzydziestych XVI wieku. W każdym razie czas tworzenia Cricianów przypadł na lata 1539-1547. Jak domyśla się Ryszard Marciniak, to sam Tomicki mógł zlecić Górskiemu zebranie pism swego siostrzeńca Andrzeja Krzyckiego, gdzieś w drugiej połowie lat dwudziestych XVI wieku (BK 243; Biblioteka Ossolineum, dalej cyt. B. Oss., rps sygn. 158, 2304). Możliwe też, że przed Tomicianami powstał, zaginiony dziś, kodeks z mowami Piotra Tomickiego ${ }^{18}$.

Słynne Teki Górskiego (Biblioteka Narodowa, dalej cyt. BN, BOZ, Teki Górskiego, t. I-XXIX) $)^{19}$ narodziły się, gdy Stanisław Górski przejął spuściznę Piotra Tomickiego, co mogło nastąpić jeszcze przed rokiem 1540. Teki są złożone z papierów urzędowych i prywatnych Piotra Tomickiego, a także kopii aktów dyplomatycznych i korespondencji z czasów panowania Zygmunta Starego. W znacznym stopniu składa się też na nie oryginalna korespondencja dyplomatyczna zarówno Tomickiego, jak i króla. W latach czterdziestych XVI wieku, gdy Górski był sekretarzem królowej, Teki wzbogaciły się o oryginalne listy Krzyckiego i Tomickiego pisane do Bony. Do Tek Górskiego dostało się wreszcie nieco materiałów z czasów zarządzania kancelarią przez Jana Chojeńskiego, co można tłumaczyć zabraniem spuścizny z kancelarii

17 Katalog rękopisów staropolskich Biblioteki Kórnickiej XVI-XVIII w., t. 2, oprac. R. Marciniak, M. Muszyński, J. Wiesiołowski, Wrocław 1985, s. 137-138.

18 R. Marciniak, dz. cyt., s. 32-34, 38.

19 Ryszard Marciniak (dz. cyt., s. 183-186) doszukuje się materiałów (lub ich fragmentów) z pracowni Stanisława Górskiego również poza dawną Biblioteką Ordynacji Zamojskiej: BK 221, BK 222, BK 1461, B. Czart. 254, B. Czart. 255, B. Czart. 261, B. Czart. 262, B. Czart. 264, B. Czart. 265, B. Czart. 276, B. Czart. 281, B. Czart. 282, B. Czart. 283, B. Czart. 284, B. Czart. 288, B. Czart. 289, B. Oss. 77, B. Oss. 158, B. Oss. 168, B. Oss. 172, B. Oss. 174, BJ 44. 
przez Stanisława Borka we wrześniu 1536 roku. Górski, zbierając materiały do Tomicianów, korzystał również z ksiąg rejestrowych Macieja Drzewickiego. Już w pierwszej redakcji Tomicianów posługiwał się nadto osobistym dziennikiem prymasa Drzewickiego, który mógł uzyskać dopiero po śmierci tegoż w roku $1535^{20}$.

Najpóźniej w roku 1547, już po ofiarowaniu kilkutomowej kolekcji materiałów politycznych Mikołajowi Radziwiłłowi „Czarnemu”, Stanisław Górski rozpoczął prace nad pierwszą redakcją Tomicianów. Kolekcja miała się początkowo składać z 13 tomów, z których 10 miało zawierać akta z lat 1507-1535 w układzie chronologicznym, tom 11 był przewidziany dla listów Tomickiego, tom 12 dla korespondencji pisanej do Rzymu w sprawach kościelnych, tom 13 dla Dantiscanów do roku 1544 (BJ 6547-6563) ${ }^{21}$. Tomiciana należy uznać za najdoskonalszy owoc zbieractwa akt politycznych w ciągu całego XVI stulecia, przy czym ich redakcja datuje się na okres panowania Zygmunta Augusta, a najszersze społeczne funkcjonowanie na ostatnie ćwierćwiecze XVI wieku. W swej linii ideowej Tomiciana propagowały model państwa rządzonego przez króla wśród senatorów. Jak zauważył zasłużony, a dawno zmarły badacz, Tomiciana „z widocznym wstrętem pomijają samoucznych polityków, szlacheckich mówców sejmowych, podając tylko wtedy obszerniejszą o nich wiadomość, gdy jak w r. 1537, głębokim króla napełnili zmartwieniem, lub jak w r. 1513 dali mu sposobność gromkiego a słusznego upomnienia" 22 .

Pierwsza próba oddania w ręce członków elity możnowładczej narzędzia pracy w postaci zbioru dokumentów zakończyła się, jak należy przypuszczać, niepowodzeniem. W roku 1545 Stanisław Górski przekazał Mikołajowi Radziwiłłowi „Czarnemu” (1515-1565) kilka ksiąg tekstów politycznych nazwanych przez Ryszarda Marciniaka Pretomicianami. Inicjatywa wyszła niewątpliwie od Górskiego. Pierwszy tom Pretomicianów Mikołaja Radziwiłła „Czarnego” z aktami spraw zagranicznych z lat 1499-1525 jest oprawiony w brązową skórę z herbem Trąby i napisem „Legationes, Responsa Regia 1545” (B. Czart. 2184/IV). Drugi tom zbierał materiały z lat 1536-1544 (korespondencja królowej Bony, utwory Klemensa Janickiego B. Czart. 282). Trzeci kodeks nie przetrwał drugiej wojny światowej - zawierał akta spraw pruskich z lat 1509-1535. Mogły istnieć kolejne woluminy

20 R. Marciniak, dz. cyt., s. 41, 47, 53, 56, 57.

21 Tamże, s. 54-55.

${ }^{22}$ Diariusze sejmów koronnych 1548, 1553 i 1570 r., wyd. J. Szujski, Kraków 1872, s. VI. 
ofiarowane „Czarnemu”, na przykład kodeks z aktami stosunków z Rzymem w latach $1513-1535^{23}$.

Radziwiłł znał łacinę słabo, do czego sam się zresztą przyznawał. W korespondencji i życiu publicznym posługiwał się niemal wyłącznie językiem polskim, choć nieobcy był mu też ruski jako język kancelaryjny Wielkiego Księstwa ${ }^{24}$. Wobec tych ograniczeń językowych nie mógł w pełni wykorzystać otrzymanego narzędzia ${ }^{25}$. Mimo to epizod ten stanowił zapowiedź powstawania w przyszłości bogato wyposażonych w reprezentatywne materiały aktowe prywatnych archiwów politycznych możnowładców. Rodzi się pytanie, czy Pretomiciana przejęli synowie „Czarnego”, zwłaszcza Jerzy i Mikołaj Krzysztof „Sierotka”, o których wysokiej kulturze archiwalnej sporo wiemy. Ryszard Marciniak był przecież zdania, że kodeksy ofiarowane Mikołajowi Radziwiłłowi „Czarnemu” szybko poszły w zapomnienie. Przeczyłby temu fakt, że zachowany tom pierwszy czytany był jeszcze zapewne w latach 1634-1635 , na co wskazują powtarzające się obliczenia, ile minęło lat od opisywanych wydarzeń do tych dat. $\mathrm{Z}$ tego samego czasu zdają się pochodzić marginalia w języku ruskim. Fakt zaglądania do kodeksu w XVII wieku nie jest oczywiście równoważny z pozostawaniem w ręku Radziwiłłów. W każdym razie istnieje problem wskazania dokładnego czasu, w którym Radziwiłłowie utracili Pretomiciana. Jeśli nie nastąpiło to jeszcze za życia „Czarnego”, to nie wydaje się, by doszło do tego w następnym pokoleniu, o czym szerzej opowiem w rozdziale traktującym o prywatnych archiwach politycznych w ostatnich dziesięcioleciach XVI wieku.

Obok grupy archiwów politycznych rozwijających się w związku z dworem lub kancelarią królewską ujawnił się w pierwszej połowie XVI wieku inny nurt, z pewnością uboższy, koncentrujący się na gromadzeniu ustawodawstwa sejmowego. Wyjątkowo tylko dysponujemy zbiorem uchwał sejmowych mających określoną przynależność proweniencyjną. W tym przypadku chodzi jednakże o przedstawiciela rodziny możnowładczej, Stanisława Łaskiego (ok. 1500-1550). Należał do niego kodeks z aktami przeważnie z czasów Zygmunta Starego, oprawiony w brązową skórę z superekslibrisem z herbem Korab i literami SL. Rozwiązanie proweniencji potwierdza nota wewnątrz kodeksu: „Sta: Lasky” (BK 902). Rękopis zawiera, oprócz kilku aktów prawodawczych z epoki Kazimierza Jagiellończyka, konstytucje sejmów $1527,1532,1538,1539,1540$ i 1544 , ale przeplatane innymi materiałami

23 R. Marciniak, dz. cyt., s. 49-50.

24 H. Lulewicz, Radziwitt Mikotaj zwany Czarnym, [w:] Polski stownik biograficzny, t. 30, Wrocław i in. 1987, s. 336.

25 R. Marciniak, dz. cyt., s. 51-52. 
z tych czasów, żeby tylko wspomnieć uniwersał zwołujący pospolite ruszenie pod Lwów w roku 1537, dekret hetmański w sprawie opłaty wojska z roku 1528 czy porządek senatu koronnego. Część kopiariusza zajmują dekrety sądowe króla.

Przykład zbierania odpisów konstytucji, którego dostarczył nam kodeks Stanisława Łaskiego, nie był w pierwszej połowie XVI wieku odosobniony. Okres ten charakteryzował się w ogóle zjawiskiem tworzenia zbiorów konstytucji sejmowych. Większość z nich nie ma określeń proweniencyjnych, można by więc założyć, że mogły być równie dobrze własnością polityków, jak i znajdować się w ręku kapituł, miast czy uczonych prawników. Jednakże nasilenie chronologiczne zachowanej spuścizny każe wiązać to zbieractwo ze wzrostem dążeń emancypacyjnych średniej szlachty. W zbiorach tych można widzieć zapowiedź przyszłych archiwów polityków egzekucyjnych doby Zygmunta Augusta. Częstsze i grupujące uchwały wielu sejmów są zbiory konstytucji z ostatnich lat panowania Zygmunta Starego, mniej więcej od czasu wojny kokoszej. Przyczyny tego częściowo wolno upatrywać w wydaniu drukiem zbioru konstytucji z lat 1507-1523, po którym nastąpiła luka aż do połowy wieku XVI. Lukę tę musiały więc zapełnić rękopiśmienne kolekcje (Archiwum Główne Akt Dawnych, dalej cyt. AGAD, Nabytki niedok. Oddz. I, sygn. 104, 105, 122; BJ 196; B. Oss. 467, 1051). Ogląd pisma pozwala połączyć w jedną kolekcję dwa zbiorki konstytucji sejmowych, jeden z uchwałami lat 1538, 1539 i 1540 (Biblioteka Uniwersytetu Mikołaja Kopernika, dalej cyt. BUMK, rps sygn. 580/III), drugi z konstytucjami 1543 roku (BUMK 579/III). Ciekawy jest wreszcie zbiór konstytucji z lat 1539-1543, należący w roku 1583 do niejakiego Łazińskiego (BK 903). Zdajemy sobie sprawę, że to, co zdołało się do dziś zachować, stanowi zaledwie ułamek tego, co krążyło w niezliczonych odpisach w epoce Zygmunta Starego.

Prywatne archiwa polityczne pierwszej połowy XVI wieku były tworzone przede wszystkim przez współpracowników królewskich, często w związku z wykonywanymi przez nich obowiązkami służbowymi. Obowiązki te mogły inspirować do zbieractwa akt politycznych na prywatny użytek. Zapowiadała się jednak dwutorowość rozwoju archiwów politycznych. Z jednej strony, powstawały elitarne skarbnice odpisów poufnych dokumentów państwowych z przeznaczeniem dla elit senatorsko-możnowładczych, z drugiej - kolekcje uchwał sejmowych jako zapowiedź koncentrujących się na problemach wewnętrznych archiwów działaczy szlacheckich następnego okresu. Od samego początku w rozwoju prywatnych archiwów politycznych odbija się zasadniczy konflikt epoki pomiędzy demokracją szlachecką a rządami senatorskimi. 


\section{Prywatne archiwa polityczne W LATACH PANOWANia Zygmunta Augusta}

W okresie panowania Zygmunta Augusta rozwinęły się archiwa działaczy szlacheckich, niewielkich rozmiarów i skoncentrowane na życiu parlamentarnym. Ważne jest również to, że archiwa poszczególnych egzekucjonistów nie były odosobnionymi od siebie tworami. Powstawały one w wyniku obiegu tej samej dokumentacji, wykazują wzajemne zależności na czele z występującą w wielu z nich kroniką wydarzeń międzysejmowych.

Przegląd tego typu archiwów zaczniemy od archiwum Hieronima Filipowskiego. Filipowski (zm. przed 1574) był posłem sejmowym i działaczem reformacyjnym. Posłował z województwa krakowskiego na sejmy 1562/1563, $1563 / 1564,1566,1567^{26}$. Materiały polityczne tego wybitnego działacza egzekucyjnego zostały zebrane w osobny kodeks. Znajdują się w nim teksty z lat 1556-1567: recesy sejmowe, uniwersały, konstytucje, diariusze sejmów 1556/1557 i 1563/1564, przegląd stosunków polsko-litewskich w latach 1385-1459 według kronik Długosza i Kromera z objaśnieniami i uwagami krytycznymi z okresu sejmów egzekucyjnych, kroniczka lat 1557-1559 (BK 256). Hieronim Filipowski posiadał także rękopis z aktami sejmowymi lat 1562-1564 (BK 249). Zawiera on diariusz sejmu piotrkowskiego 1562/1563 poprzedzony kroniką lat 1559-1562, zakończony zaś jest artykułami sejmu bielskiego z roku 1564.

Podobnie pewne jest rozpoznanie kopiariusza należącego do Jana Osmolskiego, dworzanina królowej Bony, posła na sejm 1541 roku, działacza reformacyjnego, sympatyka ruchu egzekucyjnego, posła sejmowego z województwa lubelskiego w latach 1564, 1566, 1570. Była to postać dosyć nietypowa w ówczesnym społeczeństwie szlacheckim. Krytyczny wobec swych rodaków i urządzeń krajowych, całe życie aktywny intelektualnie, rozumiejący mechanizmy gospodarki kapitalistycznej, uzdolniony w prowadzeniu interesów, nie był typem szlacheckiego trybuna. Zdegustowany wydarzeniami bezkrólewi lat 1572-1576, do czego doszły jeszcze osobiste kłopoty małżeńskie, wyemigrował z Polski. Z czasów Zygmunta Augusta pochodzi kodeks z jego superekslibrisem i zapiskami własnościowymi. Księga ta zawiera poezje Jana Kochanowskiego, materiały do zagadnień reformacyjnych, a więc listy, wyznania wiary, rozprawy teologiczne, a wreszcie materiały polityczne (np. z roku 1559: układ Zygmunta Augusta z Gotthardem Kettlerem dotyczący Inflant, dokument Zygmunta Augusta zapewniający arcybiskupowi Wilhel-

26 S. Szczotka, Filipowski Hieronim (zm. przed 1574), [w:] Polski stownik biograficzny, t. 6, Kraków 1948, s. 457-460. 
mowi i kapitule ryskiej obronę przed Moskwą, relacja o sprawach tureckich i węgierskich omawianych na sejmie Rzeszy w Augsburgu). Ważne miejsce zajmuje diariusz sejmu 1556/1557 roku (BN III 3043), przepisany od Hieronima Ossolińskiego. W latach późniejszych, już za panowania Stefana Batorego, Osmolski zapewnił sobie korespondencję informującą o przebiegu wojny polsko-moskiewskiej ${ }^{27}$.

Nie ulega wątpliwości, że dokumentację pisaną gromadził w czasie swej długoletniej działalności Mikołaj Sienicki, wielokrotny poseł i działacz reformacyjny, choć odtworzenie jego archiwum w szczegółach natrafia na znaczne trudności. Hipotezę o istnieniu archiwum politycznego Mikołaja Sienickiego można by wysunąć już na podstawie jego wyjątkowej aktywności politycznej oraz czynnego uczestnictwa w procesie tworzenia akt politycznych (autorstwo diariuszy sejmów 1555 i 1558 roku $^{28}$ ). Sienicki był umysłem otwartym. Spośród egzekucjonistów najpełniej zrozumiał, że nowe sytuacje wymagają wręcz stanowienia nowych praw. Programowo odżegnywał się od łaciny, uważając, że o polskich sprawach należy rozmawiać po polsku. Pilnował, by do swych wystąpień nie wprowadzać łacińskich wtrętów. Był zwolennikiem usprawnienia obrad sejmowych przez rozpatrywanie niektórych zagadnień przez deputacje. Intensywna praca Sienickiego podczas sejmów polegała między innymi na pilnym studiowaniu statutów i wglądaniu do archiwum koronnego. Nie dość zresztą, że sam czytał akty prawne, nie dość, że zalecał posłom czytanie ich w przerwach między obradami, to osiągnięta pozycja pozwalała mu z takimiż pouczeniami występować wobec króla i senatorów. Korzystał Sienicki ze Statutów Łaskiego, wiedział jednak, że są one zepsute wskutek zamieszczenia w nich niektórych przywilejów dla duchowieństwa, posiłkował się więc ponadto Długoszem, Miechowitą, Statutami Herburta, a wreszcie statutami starszymi niż dzieło Jana Łaskiego, których trochę jeszcze znajdowało się u szlachty, zapewne więc Syntagmatami. Wszystko to jednak mu nie wystarczyło i ułożył swój własny zbiór aktów państwowych i kościelnych, który po jego śmierci przejął Jan Zamoyski ${ }^{29}$. W świetle tego, co przywołano, jest wysoce prawdopodobne, że oprócz zbioru owych aktów kościelnych i państwowych dysponował Sienicki jeszcze przynajmniej diariuszami sejmów, których autorstwo mu się przypisuje, co wydaje się rachunkiem dosyć ostrożnym.

27 H. Barycz, Osmolski Jan (ok. 1510-1593/4), [w:] Polski stownik biograficzny, t. 24, Wrocław i in. 1979, s. 370-373.

28 S. Grzybowski, Mikołaj Sienicki-Demostenes sejmów polskich, Odrodzenie i Reformacja w Polsce, t. 2, 1957, s. 102; Katalog rękopisów staropolskich BK, t. 2, s. 466.

29 S. Grzybowski, Mikotaj Sienicki, s. 105, 108-109, 119, 121, 129-130. 
Nie zawsze jednak mamy pewność co do proweniencji materiałów politycznych. Walenty Orzechowski, brat wybitnego pisarza Stanisława, sędzia ziemski przemyski, poseł na sejmy 1563/1564, 1566, 1567, 1569 i 1572, jest domniemanym twórcą zbioru materiałów dotyczących sejmów i bezkrólewi z lat 1563-1564, 1569, 1572-1576 (BN III 3081). Sądzę, że proweniencja Walentego Orzechowskiego jest tym bardziej prawdopodobna, że w kodeksie są niezrealizowane projekty ustaw, których autorstwo wolno z nim wiązać. Jednorodność redakcji kodeksu przejawia się w długich, sumaryzujących tytułach wpisów.

Rekonstrukcyjny charakter ma również teza o archiwum politycznym Hieronima Ossolińskiego (zm. 1575 lub 1576), posła na sejmy 1548, 1550, 1552, 1553, 1555, 1556/1557, 1558/1559, 1562/1563, działacza reformacyjnego, kasztelana sądeckiego od roku 1568, wojnickiego od 1569, wreszcie sandomierskiego od roku $1570^{30}$. Idę tutaj za zdaniem Stanisława Bodniaka, który rozwinął swoje rozumowanie na marginesie wydawnictwa diariusza sejmu 1556/1557. Diariusz występuje łącznie z kroniczką lat 1557-1558. Taką samą kronikę mają rękopisy z diariuszami sejmu 1562/1563, tyle że za lata 1559-1562. Podobna kronika występuje wreszcie przy diariuszu sejmu 1548 roku. Twórca diariuszy sejmowych łączył je najwyraźniej w całość z kronikami okresów międzysejmowych. Należy go poszukiwać wśród zwolenników reformacji, a jednocześnie czynnych działaczy egzekucyjnych. Stanisław Bodniak, rozważając kwestię autorstwa diariusza sejmu 1556/1557, brał pod uwagę Hieronima Filipowskiego lub Hieronima Ossolińskiego, przychylając się do drugiej ewentualności. Za Ossolińskim mają przemawiać: biegłość w prawie i historii, znajomość dokumentów państwowych, zwłaszcza z zakresu stosunków polsko-litewskich, skwapliwość do pióra, redagowanie aktów ustawodawczych, staranne przygotowywanie mów sejmowych na piśmie. Ponadto uważa się Ossolińskiego za autora diariuszy sejmów lat 1553, 1555 i 1558/1559. Zdaniem Stanisława Bodniaka diariusz sejmu 1556/1557 ma z nimi wspólne cechy redakcyjne, między innymi wysuwanie na czoło osoby Hieronima Ossolińskiego. W konkluzji Bodniak przyznał Ossolińskiemu nie tylko autorstwo wydawanego przez siebie drukiem diariusza, ale też dziennika sejmu 1548 roku, a dalej redakcję całego zbioru diariuszy sejmowych połączonych kroniką wydarzeń okresów między sejmami ${ }^{31}$. Gdyby domysł Stanisława Bodniaka potwierdził się, usprawiedliwione byłoby dopatrywanie

30 I. Kaniewska, Ossoliński Hieronim (zm. między 1575 a 1576), [w:] Polski stownik biograficzny, t. 24, s. 396-399.

31 Diariusz sejmu walnego warszawskiego z roku 1556/7, wyd. S. Bodniak, Kórnik 1939, s. 7-9. 
się wyjątkowo bogatego archiwum politycznego u Hieronima Ossolińskiego. Faktem jest w każdym razie, że na sejmie 1553 roku powołał się on na akt unii mielnickiej z 1501 roku, którego kopię miał przy sobie. Dysponujemy też innymi dowodami wykorzystywania przez Ossolińskiego dokumentów politycznych podczas dyskusji na temat stosunku prawnego Polski i Litwy ${ }^{32}$. Podczas sejmu piotrkowskiego 1562/1563 roku Ossoliński, przygotowując odpowiedź biskupom w sprawie dziesięcin, opracował prawdopodobnie przegląd przywilejów stanowych szlachty z punktu widzenia tejże szlachty, w którym oparł się na Statutach Łaskiego (BK 249) ${ }^{33}$.

$\mathrm{Na}$ ślad archiwum anonimowego Małopolanina natrafiamy przy okazji kodeksu zawierającego diariusz sejmu 1569 roku z późniejszym dodatkiem dwóch mów z sejmu 1605 (BK 258). Proweniencja małopolska nie podlega dyskusji. Diariusz eksponuje poczynania posłów i senatorów województwa krakowskiego, przed właściwym opisem sejmu dano natomiast akta sejmiku proszowickiego z końca 1568 roku (k. 6-11v). Na proweniencję małopolską wskazuje wreszcie jedna z zapisek marginalnych przy uchwałach sejmiku proszowickiego, pochwalająca instytucję sejmików nowokorczyńskich (k. 11). Zaryzykujmy nawet stwierdzenie, że twórcą archiwum był działacz średnioszlachecki z województwa krakowskiego. W literaturze wskazuje się na Stanisława Szafrańca, a to ze względu na podkreślenie jego nazwiska w wykazie posłów proszowickich oraz dokładniejsze niż w przypadku innych posłów pokazanie jego działalności sejmowej ${ }^{34}$. Aktywność polityczna Szafrańca, działacza egzekucyjnego, potem kasztelana bieckiego, sandomierskiego i wojewody sandomierskiego, zmarłego w 1598 roku $^{35}$, rzeczywiście czyni domysł bardziej prawdopodobnym.

Ktoś z kolei, kto używał inicjałów M T D L - takie litery widnieją na superekslibrisie wytłoczonym na pomarańczowym pergaminie $\mathrm{z}$ herbem Strzemię i dewizą „Frustra vivit, qui nemini prodest” - był twórcą lub posiadaczem kodeksu z aktami sejmów 1562/1563 i 1563/1564 z dodaniem materiałów od 1559, a potem z 1573 roku i z pierwszych lat panowania Batorego (B. Czart. 2208). Kodeks w czasach Batorego mógł znajdować się w ręku Piotra Strzały, sędziego zatorskiego i poborcy województwa krakowskiego. $\mathrm{Na}$

32 I. Kaniewska, dz. cyt., s. 396.

33 Katalog rękopisów staropolskich BK, t. 2, s. 408.

34 Tamże, s. 470.

35 Urzędnicy województwa krakowskiego XVI-XVIII wieku. Spisy, oprac. S. Cynarski, A. Falniowska-Gradowska, red. A. Gąsiorowski, Kórnik 1990, s. 45, 261; Urzędnicy województwa sandomierskiego XVI-XVIII wieku. Spisy, oprac. K. Chłapowski, A. Falniowska-Gradowska, red. A. Gąsiorowski, Kórnik 1993, s. 91, 124. 
proweniencję z archiwum Strzały wskazywałyby akta poborowe, które wpisano w wolne miejsce wbrew koncepcji kodeksu (s. 353 i n.). Domysł umacnia biografia Piotra Strzały biorącego czynny udział w życiu publicznym: w sejmie lubelskim 1569 roku, a wiele lat później w sejmie koronacyjnym Zygmunta Wazy ${ }^{36}$.

Przy okazji śledzenia pozostałości archiwów małopolskich warto zwrócić uwagę na jednostkę przypisywaną Janowi Spytkowi Tarnowskiemu (zm. 1553), kolejno kasztelanowi żarnowskiemu, zwichojskiemu, radomskiemu i wojnickiemu, wojewodzie sieradzkiemu, a przede wszystkim podskarbiemu koronnemu w latach $1532-1550^{37}$, złożoną z konstytucji sejmu piotrkowskiego roku 1544, sejmu warszawskiego roku 1557, uchwał sejmowych dla Mazowsza z roku 1543 i wreszcie konstytucji sejmowych z 1550 (AP Kraków, Archiwum Dzikowskie Tarnowskich, sygn. 122, s. 177-192). Należy on do wczesnego okresu dziejów archiwów politycznych, może też stąd bierze się prostota koncepcji. Pewną wątpliwość co do realnego istnienia jednostki w XVI wieku może budzić fakt pozostawania jej w formie luzów. Jednakże zabrudzenia, wytarcia i naddarcia brzegów, plamy, rozległość zniszczeń oraz tematyka wskazują na długie wspólne chowanie. Co więcej, na odwrociu drugiej karty konstytucji z roku 1544 zaczynają się już konstytucje sejmu 1557, co przesądza chyba sprawę integralności materiałów, a nawet każe się zastanawiać, czy nie przewidywano ich współoprawności. Jednocześnie fakt, że zbiór wykracza poza datę śmierci Jana Spytka Tarnowskiego, każe widzieć jego kontynuatorów w kolejnym pokoleniu Tarnowskich.

Opuszczając Małopolskę, trzeba stwierdzić, że anonimowy Wielkopolanin był właścicielem rękopisu zawierającego kolejno: konstytucje sejmów Zygmunta Starego (1527, 1532, 1538, 1539, 1540, 1542-1543) oraz dwa potwierdzenia generalne praw Zygmunta Starego z roku 1530 i Zygmunta Augusta z roku 1537, dalej opis kronikarski wydarzeń parlamentarnych od roku 1544, odnotowujący zmianę panującego w roku 1548, i opis wypadków w pierwszych latach panowania Zygmunta Augusta, wreszcie kilka aktów z tego czasu: list królewski na ręce starosty generalnego Wielkopolski Andrzeja Górki zwołujący sejm oraz sejmiki w Środzie i Kole w roku 1548, uchwały sejmo-

36 K. Niesiecki, Herbarz polski, t. 8, Lipsk 1841, s. 544.

37 Urzędnicy centralni i nadworni Polski XIV-XVIII wieku. Spisy, oprac. K. Chłapowski, S. Ciara, Ł. Kądziela, T. Nowakowski, E. Opaliński, G. Rutkowska, T. Zielińska, red. A. Gąsiorowski, Kórnik 1992, s. 124, 209; Urzędnicy województwa sandomierskiego, s. 165, 161, 69; Urzędnicy województwa krakowskiego, s. 131; Urzędnicy województw tęczyckiego i sieradzkiego XVI-XVIII wieku. Spisy, oprac. E. Opaliński, H. Żerek-Kleszcz, red. A. Gąsiorowski, Kórnik 1993, s. 176. 
we z roku 1552 i dekret dla Wielkopolski w sprawach sądowych z sejmu 1553 roku. Kodeks nie ma zresztą zakończenia (BK 901). Mamy tu zatem do czynienia z jednostką świadomie koncentrującą się na życiu parlamentarnym czasów Zygmunta I i początków epoki jego syna.

Brak pewniejszych danych, poza jednym opisanym wyżej kodeksem, nie oznacza, że wielkopolscy działacze egzekucyjni nie gromadzili archiwaliów. $\mathrm{Na}$ tropie ich archiwów znalazła się być może Irena Kaniewska, gdy rozpatrywała autorstwo diariusza sejmu 1566 roku. Wskazała wówczas hipotetycznie na osoby Jakuba Ostroroga, Wojciecha i Stanisława Czarnkowskich, ewentualnie Rafała Leszczyńskiego ${ }^{38}$, którym w związku z tym warto byłoby się krótko przyjrzeć jako wielkopolskiej elicie szlacheckiej doby sejmów egzekucyjnych.

Wojciech Sędziwój Czarnkowski (zm. 1578), kasztelan santocki od roku 1563, generał wielkopolski, posłował też na sejmy egzekucyjne ${ }^{39}$, ale trudno powiedzieć coś więcej na temat możliwości tworzenia przezeń archiwum politycznego. Ciekawsza z tego punktu widzenia wydaje się osoba jego brata, Stanisława Sędziwoja Czarnkowskiego (1526-1602), posła poznańskiego na sejmy 1562/1563, 1563/1564, 1565, 1566, 1567 i 1569, którego był zresztą marszałkiem. Na tym ostatnim sejmie Czarnkowski wyraził w swej mowie pragnienie, by zawarto z Litwą unię na podstawie aktu z roku 1501. W przeszłości szukał też uzasadnienia przyłączenia Kijowszczyzny do Korony, mianowicie w wyprawach Bolesławów Chrobrego i Śmiałego. Znajomość prawa polskiego miała mu dać praca w archiwum koronnym za Zygmunta Augusta. W roku 1564 posłował do książąt pomorskich, w latach 1568, 1570 i 1571 do Zofii brunszwickiej. W roku 1567 został referendarzem koronnym. Aktywnie uczestniczył w bezkrólewiach lat 1572-1576. Marszałkował na sejmie koronacyjnym Henryka Walezego. Za Batorego stale bywał wybierany posłem z województwa poznańskiego, stojąc na stanowisku wrogim królowi z powodu osobistej urazy po nienadaniu mu koadiutorii gnieźnieńskiej. Na sejmie w roku 1582 król zażądał od niego zwrotu dokumentów, które wydał mu jeszcze Zygmunt August, gdy Czarnkowski posłował do Niemiec w sprawie wiana Zofii Jagiellonki. Czarnkowski dokumenty te zwrócił dopiero, gdy został skazany zaocznie na infamię. Na sejmie 1585 roku powołał się na przywilej z 1501 roku, żądając, żeby Krzysztofa Zborowskiego sądził nie król, a senat w obecności izby poselskiej. W czasie bezkrólewia po Batorym energicznie popierał kandydaturę habsburską. Brał udział w życiu parlamentarnym w la-

38 Diariusz sejmu lubelskiego 1566 roku, wyd. I. Kaniewska, Wrocław 1980, s. X.

39 Por. A. Dembińska, Czarnkowski Wojciech Sędziwój (zm. 1578), [w:] Polski stownik biograficzny, t. 4, Kraków 1938, s. 225-226. 
tach panowania Zygmunta III. W roku 1596 powołano go do komisji mającej rozpatrzyć sprawę ligi antytureckiej. W ogóle jednak był to demagog, okrywający osobistą zemstę za niedopuszczenie do wielkiej kariery hasłami obrony wolności szlacheckich. Posuwał się nawet do płatnego szpiegostwa na rzecz Habsburgów ${ }^{40}$. W całym życiu Stanisława Czarnkowskiego widać obycie z aktami w działalności politycznej, co uprawdopodobnia w jego przypadku gromadzenie archiwaliów politycznych.

Trzeci z Wielkopolan, Rafał Leszczyński, był starostą radziejowskim, a prócz tego wojewodą brzesko-kujawskim już od roku 1545. Pięć lat później wobec szlachty zgromadzonej na sejmie dobrowolnie zrezygnował z województwa, zachowując starostwo radziejowskie, gdyż rozumiał, że w myśl prawa nie można łączyć urzędu wojewody ze starostwem grodowym w tym samym województwie. Ten krok zjednał mu oczywiście ogromną sympatię szlachty. Leszczyński stał się odtąd czołowym posłem egzekucyjnym. Uczestniczył w sejmach 1552, 1555, 1558/1559, 1562/1563 (na tym sejmie marszałkował izbie poselskiej), 1563/1564, 1566, 1569. Na elekcji roku 1573 znów był marszałkiem koła rycerskiego. Ostatecznie w roku 1580 wrócił do senatu jako kasztelan śremski ${ }^{41}$. Przypisuje się niekiedy Leszczyńskiemu autorstwo diariusza sejmu 1570 roku. Diariusz ten miał on opracować co prawda na podstawie innych przekazów, gdyż sam w tym czasie posłował do Moskwy, i przesłać go Maksymilianowi $\mathrm{II}^{42}$. Istnieją jednakże głosy przeczące tezie o autorstwie Leszczyńskiego. Niezależnie od stanu faktycznego należy podkreślić, że Rafał Leszczyński prowadził rozległą korespondencję z dworami królewieckim i wiedeńskim, a podczas sejmów słynął jako znakomity znawca konstytucji ${ }^{43}$. Wzmacnia to hipotezę o narastaniu archiwum politycznego Rafała Leszczyńskiego.

Ostatni z typowanych na ewentualnych twórców archiwów politycznych Wielkopolan, Jakub Ostroróg (ok. 1516-1568), generał wielkopolski, protektor braci czeskich, posłował na sejmy 1555, 1558, 1565 i $1566^{44}$. Brakuje jednak przesłanek na korzyść tezy o istnieniu jego archiwum politycznego.

40 K. Lepszy, Czarnkowski Stanistaw Sędziwój (1526-1602), [w:] Polski stownik biograficzny, t. 4, s. 221-225.

41 M. Sipayłło, Leszczyński Rafat (ok. 1526-1592), [w:] Polski stownik biograficzny, t. 17, Wrocław i in. 1972, s. 132-135.

42 J. Pirożyński, Sejm warszawski roku 1570, Kraków 1972, s. 6.

43 M. Sipayłło, dz. cyt., s. 133.

44 M. B. Topolska, Ostroróg Jakub (ok. 1516-1568), [w:] Polski stownik biograficz$n y$, t. 24, s. 500-502. 
Prywatne archiwa polityczne za panowania Zygmunta Augusta powstawały także poza obozem egzekucyjnym, mianowicie w środowisku skupionym wokół dworu królewskiego, podobnie zresztą jak w poprzednim okresie. W tym kontekście można przyjrzeć się Marcinowi Kromerowi (1512-1589). Z osobą Kromera wiąże się kopiariusz dokumentów z Archiwum Koronnego Krakowskiego z okresu od XIII wieku do roku 1501 (BK 203). Proweniencja rękopisu była różnie określana, przy czym wskazywano całkiem bezzasadnie na jego pochodzenie z archiwum Jana Zamoyskiego czy Jana Łaskiego. Nie ma dziś powodu, by kwestionować inne rozwiązanie, oparte na analizie ręki pisarskiej, znaków wodnych, jak i treści wpisów i zapisek marginalnych, wskazujące na Marcina Kromera ${ }^{45}$. Nie ulega też wątpliwości, a świadectwem niezbitym jest typowa oprawa z superekslibrisem, że w końcu XVI wieku kodeks znalazł się w ręku Andrzeja Opalińskiego seniora i na jego polecenie uzyskał wygląd zewnętrzny analogiczny do reszty jego kodeksów. Z not marginalnych w kopiariuszu wynika, że Kromer sporządził jeszcze dwa kodeksy: jeden spraw pruskich, drugi węgierskich - dziś nieznane ${ }^{46}$. I wreszcie pismo identyczne z pismem kopiariusza wyżej opisanego zmusza do przyporządkowania archiwum Marcina Kromera zniszczonego w czasie drugiej wojny światowej jeszcze jednego kodeksu zbierającego odpisy dokumentów Archiwum Koronnego Krakowskiego: piętnastowiecznych traktatów pomiędzy Polską a cesarzem i książętami Rzeszy, jak również czternastowiecznych i piętnastowiecznych kopii aktów ilustrujących stosunek lenny Pomorza względem cesarstwa. Oprawa świadczy o tym, że i ten rękopis przeszedł z czasem w ręce Andrzeja Opalińskiego starszego ${ }^{47}$.

Trzeba pamiętać, jak świetną okazję do sformowania serii opisanych kopiariuszy miał Kromer w trakcie porządkowania archiwum koronnego w połowie wieku. Jako sekretarz królewski na polecenie Zygmunta Augusta, korzystając z pomocy pisarzy, zregestował i uporządkował 843 dokumenty w skarbcu wawelskim. Praca ta, utrwalona w pierwszym inwentarzu Archiwum Koronnego Krakowskiego, trwała od września 1550 do października 1551 roku. Dokumenty ułożył Kromer w osiemnaście działów, według przynależności państwowo-terytorialnej. W literaturze zaznacza się, że porządko-

45 Por. Katalog rękopisów staropolskich Biblioteki Kórnickiej XVI-XVIII w., t. 1, oprac. R. Marciniak, M. Muszyński, J. Wiesiołowski, Wrocław 1971, s. 504-505.

46 O regestrze pruskim mowa jest w BK 203 na przykład na k. 88, 89, 92, 93; o węgierskim w BK 203 na k. 75, 77, 77v. Tego samego zdania co do istnienia tych dwóch kodeksów jest Katalog rękopisów staropolskich BK, t. 1, s. 505.

47 Opis zaginionego kodeksu BK 204 patrz: Katalog rękopisów staropolskich BK, t. 1, s. 506-508. 
wanie archiwum krakowskiego dało Kromerowi świetną znajomość ustroju państwa, którą wykorzystał jednak głównie jako historyk. Inwentaryzując archiwum koronne, Kromer zwracał szczególną uwagę na dokumentację stosunków zagranicznych, z wewnętrznych interesowały go tylko ogólnopaństwowe $^{48}$. Trzeba się więcej niż domyślać, że w ręku Marcina Kromera pozostał zapewne jeden egzemplarz inwentarza archiwum koronnego z roku 1551 (B. Oss. 134).

Można się zastanawiać, czy własnością Kromera był kodeks zawierający akta jego legacji do cesarza Ferdynanda w latach 1558-1560 i do 1563, czy też wchodził on w skład ksiąg poselskich Metryki Koronnej? Znany jest nam dziś w kopii z XVIII wieku, którą sporządzono z egzemplarza mającego znajdować się w kościele w Rohatynie. Co więcej, kodeks ten występował jako całość z co najmniej jednym jeszcze, skoro na karcie 41 odpisu mówi się: „reliqua in alio volumine” (B. Oss. 155). Tytuł - Acta legationis Martini Cromeri transcripta ex authographo quod conservatur in archivo Ecclesiae Rohatinensis in diecoesis Premislensi - może wskazywać na prywatny charakter kodeksu. Starostwo rohatyńskie było w ręku Andrzeja Opalińskiego, wiemy zaś, że właśnie Opaliński wszedł w posiadanie kopiariuszy Kromera. O innych materiałach Marcina Kromera dowiadujemy się z faktu, że w roku 1573 podarował on Janowi Kostce, podskarbiemu pruskiemu, kopie listów królewskich i akt publicznych z lat $1527-1570^{49}$.

W latach późniejszych, zwłaszcza już po zgonie Zygmunta Augusta, Marcin Kromer przebywał najchętniej na Warmii. Nie znaczy to jednak, że nie interesował się wypadkami ogólnopolskimi. Informacji o zdarzeniach zachodzących w Krakowie i okolicy, jak i o wszystkim, o czym z jakichkolwiek źródeł zdołał się dowiedzieć, dostarczał mu Tomasz Płaza (1530-1593), proboszcz kościoła św. Szczepana w Krakowie, protegowany Kromera ${ }^{50}$. Informatorem Kromera był także Jerzy Tyczyn, piszący mu przez trzy dziesięciolecia o godnych pamięci wydarzeniach i życiu codziennym Rzymu, o wojnach religijnych we Francji, konflikcie chrześcijaństwa z Turcją czy powstaniu ni-

48 S. Kutrzeba, Historia źródet dawnego prawa polskiego, t. 2, Lwów 1926, s. 365; H. Barycz, Kromer Marcin (1512-1589), [w:] Polski stownik biograficzny, t. 15, Wrocław i in. 1970, s. 322-323; R. Marchwiński, Wstęp, [w:] M. Kromer, Polska, czyli o potożeniu, ludności, obyczajach, urzędach i sprawach publicznych Królestwa Polskiego księgi dwie, Olsztyn 1977, s. XII.

${ }^{49}$ R. Marchwiński, Akta podskarbich pruskich z przetomu XVI i XVII wieku w archiwum toruńskim, Zeszyty Naukowe Uniwersytetu Mikołaja Kopernika w Toruniu, Historia 5, 1969, s. 61.

${ }^{50}$ J. Małłek, Wstęp, [w:] M. Kromer, Historyja prawdziwa o przygodzie żatosnej ksiażęcia finlandzkiego Jana i królewny polskiej Katarzyny, Olsztyn 1983, s. XIII-XIV. 
derlandzkim ${ }^{51}$. W roku 1587 Marcin Kromer korzystał z usług Pawła Manuciusa Henika przesyłającego listy zawierające diariusz sejmów konwokacyjnego i elekcyjnego (B. Czart. 328).

Przedstawiciele rodziny Kostków, których członek został wymieniony przy okazji omawiania archiwum Marcina Kromera, mieli do czynienia z dokumentacją życia politycznego już za panowania Zygmunta Augusta. Jako komisarz królewski do Prus Książęcych w roku 1566 Jan Kostka (ok. 1529-1581), dworzanin i sekretarz królewski, podskarbi pruski, kasztelan gdański, prezes Komisji Morskiej, na koniec zaś wojewoda sandomierski od roku $1574^{52}$, gromadził dokumentację misji i zapiski w celu sporządzenia później diariusza-sprawozdania ${ }^{53}$. Wiemy ponadto, że w roku 1573 Marcin Kromer podarował Janowi Kostce odpisy listów i akt publicznych z lat 1527-1570. Na Jana Kostkę jako twórcę archiwum politycznego wskazuje również fakt, że potrafił on wiele konstytucji sejmowych cytować z pamięci ${ }^{54}$. Aktami publicznymi interesowali się także inni podskarbiowie pruscy tego czasu, jak Jan Dulski (zm. 1590) czy zwłaszcza Jerzy Kostka. W ogóle trzeba pamiętać, że podskarbstwo pruskie pozostawało przez większość XVI wieku w ręku Kostków. Trudno oddzielić ich zainteresowanie prywatne sprawami ogólnokrajowymi od zainteresowania niejako z urzędu i w ślad za tym zbierania akt określonych w literaturze jako informacyjne, mających dawać podskarbim rozeznanie w sprawach Rzeczypospolitej. W każdym razie owe akta informacyjne, listy, konstytucje, instrukcje sejmikowe, diariusze uroczystości dworskich znajdowały schronienie w archiwum podskarbich pruskich ${ }^{55}$.

$\mathrm{Na}$ epokę Zygmunta Augusta przypada również początek archiwum politycznego rodziny Działyńskich, choć znacznie ciekawsze materiały pochodzą z okresu późniejszego. Proweniencja archiwalna w tym wypadku jest o tyle pewna, że archiwalia te miały szczęście do pozostawania w ręku rodziny, a potem w powstałej dzięki staraniom jej przedstawicieli fundacyjnej Bibliotece Kórnickiej aż do najbliższych nam czasów. Najstarszym rękopisem w archiwum politycznym Działyńskich mógł być zaginiony podczas drugiej wojny światowej kodeks zawierający konstytucje sejmów egzekucyjnych

${ }^{51}$ Georgii Ticinii ad Martinum Cromerum Epistulae (a. 1554-1585), wyd. J. Axer, Wrocław 1975, s. 9.

${ }^{52}$ H. Kowalska, Kostka Jan (ok. 1529-1581), [w:] Polski stownik biograficzny, t. 14, Wrocław i in. 1968-1969, s. 345-348.

53 S. Bodniak, Z. Skorupska, Jan Kostka, kasztelan gdañski, prezes Komisji Morskiej i rzecznik unii Prus z Korona, Gdańsk 1979, s. 167-168.

54 Tamże, s. 24.

55 R. Marchwiński, Akta podskarbich pruskich, s. 59-62. 
kolejno od 1562/1563 do 1567 roku, w tym wiele w postaci druków, a także inne akta związane z tymi sejmami, jak i w ogóle akta z czasów Zygmunta Augusta (BK 259) ${ }^{56}$. Na pochodzenie z archiwum Działyńskich wskazuje związek wielu tekstów z ziemią dobrzyńską, a także wprost z Działyńskimi. Osoba Michała Działyńskiego jako starosty dobrzyńskiego pojawia się przy okazji aktów raczej administracyjnych, Paweł Działyński zaś występuje jako poseł króla polskiego (obok Marcina Kromera) na zjazd Hanzy w Stralsundzie w roku 1567.

Z okresu po roku 1572 zachował się do naszych czasów inny interesujący rękopis (BK 285). O pochodzeniu z archiwum Działyńskich mogą świadczyć dwa fakty: związek treści akt z końca XVI i początku XVII wieku z różnymi przedstawicielami tej rodziny oraz niewątpliwa proweniencja rękopisu od pierwszej połowy XVIII wieku, kiedy to podpisał się na nim starosta nakielski Marcin Działyński. Sprawę komplikuje okoliczność, że omawiany rękopis pochodzi z XVII wieku, należy jednak przyjąć, że stanowi on ślad archiwum Działyńskich z XVI stulecia, możliwe, że złożonego wtedy z aktów luźnych. Trudno przypisać jednostkę jednemu konkretnemu Działyńskiemu, co zresztą jest dla tej rodziny charakterystyczne. Najwięcej materiałów wiąże się z Łukaszem Działyńskim (ok. 1556-1583), starostą brodnickim i kowalewskim, podczaszym nadwornym koronnym. Łukasz był ożeniony z przyrodnią siostrą Jana Zamoyskiego. Brał udział w wojnach moskiewskich Batorego. Posłował od króla na sejmik łasiński w styczniu $1581 \mathrm{roku}^{57}$. Z jego osobą są powiązane: diariusz obozowy z wyprawy Batorego na Wielkie Łuki w roku 1580; instrukcje królewskie udzielone Łukaszowi na sejmiki pruskie w roku 1581: łasiński ze stycznia, grudziądzki z kwietnia i malborski z grudnia; odpowiedź stanów pruskich z sejmiku grudziądzkiego; być może też fragment diariusza sejmu 1582 roku.

Znając już dbałość rodziny Działyńskich o rejestrowanie publicznej działalności jej reprezentantów, dającą się zaobserwować nieprzerwanie od XVI do XIX wieku, łatwiej będzie przyporządkować kolejną jednostkę, a przynajmniej jej fragment, do archiwum politycznego Działyńskich. Chodzi tutaj o akta poselstwa Pawła Działyńskiego do Niderlandów i Anglii w roku $1597^{58}$, przechowywane dziś w Bibliotece Kórnickiej utworzonej przez tychże

56 Zawartość kodeksu została zrekonstruowana w: Katalog rękopisów staropolskich $B K$, t. 2, s. 473-477.

57 S. Bodniak, Dziatyński Eukasz (zm. 1583), [w:] Polski stownik biograficzny, t. 6, Kraków 1948, s. 89-90.

58 Por. Merkuriusz sarmacki z Niderlandów i Anglii, czyli zwięzta relacja z dwóch poselstw do Niderlandów i Anglii, które z woli Najjaśniejszego i najpotężniejszego Króla Polski 
Działyńskich. Problem polega na tym, że jednostka składa się z luzów, które można rozdzielić na sześć całostek (BK 1541). Rękopis w obecnej formie został uformowany zapewne dopiero w XIX wieku. Niektóre całostki noszą ślady zszycia i klejenia na grzbiecie, trzeba też mieć na uwadze, że pewne akty powtarzają się w różnych całostkach, i to w różnych wersjach. Najpewniej jednak niektóre przynajmniej fragmenty znalazły się w ręku Pawła Działyńskiego, jak np. oryginał odpowiedzi w imieniu królowej Elżbiety na mowę polskiego posła. Możemy nawet zaryzykować twierdzenie, że akt ten nigdy już z rąk Działyńskiego nie wyszedł, co nie stanowiłoby wyjątkowej sytuacji. Dziwne też byłoby, gdyby Paweł Działyński zachował jedynie tę odpowiedź. Można przyjąć, że posiadał zasadniczy zrąb dokumentacji poselstwa, a więc uwierzytelnienie królewskie, instrukcje dyplomatyczne, odpowiedzi, sprawozdanie z poselstwa.

Panowanie Zygmunta Augusta to jednocześnie okres najintensywniejszych prac Stanisława Górskiego nad zbiorem tekstów politycznych. Około roku 1550 powstała jego pracownia, w której zatrudnieni kopiści przygotowywali kolejne kolekcje Tomicianów. Stanisław Górski zaplanował początkowo Tomiciana na trzynaście tomów. Miał je gotowe już w roku 1553 i wówczas najpewniej trafiły do rąk Zygmunta Augusta. Jak domyśla się Ryszard Marciniak, źródeł tego kroku należy szukać w zaangażowaniu polityczno-kontrreformacyjnym Górskiego. Po wykonaniu trzynastu tomów pierwszej redakcji z materiałami do roku 1535 Górski rozpoczął redagowanie sześciu następnych ${ }^{59}$.

Pracą Górskiego interesował się Zygmunt August, którego zgoda była niezbędna dla udostępnienia Górskiemu Metryki Koronnej. W dniu 18 lutego 1557 roku Stanisław Górski z polecenia króla otrzymał 500 złotych na kontynuowanie Tomicianów. Zdaniem Ryszarda Marciniaka Zygmunt August „potrzebował przewodnika po mało znanych mu obszarach dyplomacji polskiej czasów ojcowskich". Dlatego też, gdy otrzymał od Górskiego trzynaście tomów Tomicianów, zlecił mu zapewne doprowadzenie dzieła do śmierci Zygmunta Starego. Pracę tę wykonał Stanisław Górski do roku 1557/1558, korzystając tym razem obszernie z Metryki Koronnej. Druga część kolekcji Zygmunta Augusta została podarowana królowi być może dopiero w końcu 1558 roku, gdy zjechał on wreszcie do Krakowa ${ }^{60}$.

i Szwecji etc. i za zgoda jego dostojników, senatorów i sejmu gorliwie i chwalebnie sprawowat i uczynit stawnemi oświecony i wspaniaty pan Pawet Dziatyński Roku Pańskiego 1597, wyd. R. Marciniak, Wrocław 1978.

59 R. Marciniak, dz. cyt., s. 58, 64, 80.

60 Tamże, s. 59-61, 66. 
Zwód Tomicianów Zygmunta Augusta zachował się niemal w całości, a mianowicie tomy: drugi z materiałami lat 1513-1517 (BJ 6547), trzeci za lata 1518-1520 (BJ 6548), piąty za lata 1524-1525 (BJ 6549), szósty za lata 1526-1527 (BJ 6550), siódmy za lata 1528-1529 (BJ 6551), ósmy za lata 1530-1532 (BJ 6552), dziewiąty za lata 1533-1534 (BJ 6553), dziesiąty za rok 1535 (BJ 6554), jedenasty z listami Tomickiego grupowanymi według adresatów (BJ 6555), dwunasty z aktami spraw kościelnych (BJ 6556), trzynasty z aktami poselstw Jana Dantyszka do cesarzy Maksymiliana i Karola (BJ 6557), czternasty z aktami roku 1536 (BJ 6558), piętnasty za lata 1537-1539 (BJ 6559), szesnasty za lata 1540-1541 (BJ 6560), siedemnasty za lata 1542-1543 (BJ 6561), osiemnasty za lata 1544-1546 (BJ 6562), dziewiętnasty za lata 1547-1548 (BJ 6563).

Prócz Tomicianów jeszcze około 1553 roku Stanisław Górski podarował królowi kodeks z dziełami Kallimacha. Dostęp do pism Kallimacha mógł mieć Górski poprzez papiery pozostałe po Macieju Drzewickim, który ocalił z kolei spuściznę swego mistrza, albo za pośrednictwem Fryderyka Jagiellończyka, który otrzymał na mocy testamentu bibliotekę Kallimacha, i Piotra Tomickiego (BN III.3037).

Trzeba zauważyć, że Górski obok Tomicianów gromadził w tym czasie także Orichoviana. Ze znanych kodeksów jeden, powstały do 1556 roku, mógł stanowić dodatek do Tomicianów królewskich, drugi, datowany na czas po roku 1563, własność osobistą Górskiego ${ }^{61}$.

Przekazawszy królowi sześć tomów dodatkowych Tomicianów, Górski przystąpił do redagowania zwodu siedemnastotomowego, zwanego później sapieżyńskim. Redakcja liczyła szesnaście tomów w układzie chronologicznym z lat 1507-1548 i jeden tom dodatkowy spraw kościelnych. Kolekcja została ukończona do roku 1563. Od tego roku Górski pracował nad trzecią redakcją Tomicianów, znaną dziś w zwodach Opalińskiego i Karnkowskiego. Najwięcej nowych wówczas materiałów pochodziło z ksiąg rejestrowych Macieja Drzewickiego. Znikały natomiast teksty mniej istotne politycznie, a których obecność usprawiedliwiała koncepcja renesansowego pomnika epistolografii. Analiza dat pozostawianych na papierach z Tek Górskiego skłoniła Ryszarda Marciniaka do uznania, iż zwód Opalińskiego powstawał w latach 1563-1566, zwód Karnkowskiego zaś 1566-1571. Późniejszy zwód Karnkowskiego do śmierci Górskiego w roku 1572 stanowił jego prywatną własnośćc2 .

W roku 1567 Stanisław Górski podarował senatorom koronnym pierwszy komplet Tomicianów trzeciej redakcji ${ }^{63}$. Ofiarowując Tomiciana senato-

\footnotetext{
61 Tamże, s. 78.

62 Tamże, s. 69-70, 72-75, 78.

63 Tamże, s. 89.
} 
rom, przeznaczał je do użytku wewnętrznego panów rad, w żadnym zaś razie do rozpowszechnienia ${ }^{64}$. Redakcja liczyła 24 tomy w układzie chronologicznym, następnie trzy tomy tematyczne liczbowane (sprawy kościelne, korektura praw z 1532 roku i jeden nieznany) oraz dodatkowe pięć tomów nieliczbowanych (Opera Kallimacha, Poemata Krzyckiego, Poemata Jana Dantyszka, korektura praw z 1532 roku, pisma Tomickiego z okresu jego pracy w kancelarii kardynała Fryderyka Jagiellończyka). Jak domyśla się Ryszard Marciniak, również w roku 1567 Stanisław Górski podarował Tomiciana, jedyny komplet siedemnastotomowej redakcji drugiej, senatowi litewskiemu. Tomicianami ofiarowanymi senatowi polskiemu mógł zaopiekować się albo prymas, albo marszałek koronny ${ }^{65}$.

Początkowo Stanisław Górski pragnął, ocalając pisma swego patrona Tomickiego, wystawić mu humanistyczny pomnik. Gromadząc materiały do zamierzonego pomnika Tomickiego, z czasem Górski zrozumiał, że to, z czym się styka, wykracza znacznie poza ramy epistolografii i retoryki humanistycznej. W takich okolicznościach musiał dostrzec prymat polityki nad humanizmem w korespondencji Tomickiego. Użyteczności Tomicianów dla tych, którzy mają radzić o Rzeczypospolitej, upatrywał Górski już w tym, że ukazują one wydarzenia polityczne oraz ich przyczyny. W ciągu paru dziesiątków lat zmieniła się zupełnie koncepcja Tomicianów z humanistycznej na polityczną. Wzrost roli senatu z chwilą wymarcia Jagiellonów przewidywał Stanisław Górski. Ofiarowując senatorom Tomiciana, chciał ich uzbroić zarówno przeciw obozowi szlacheckiemu, jak i reformacji, skoro król zawiódł nadzieje w tym zakresie ${ }^{66}$.

Prace Stanisława Górskiego wydały owoce jeszcze za jego życia. Zainspirowany zapewne wspaniałym darem w postaci akt do panowania jego ojca, Zygmunt August rozpoczął gromadzenie materiałów do własnego panowania. Wśród oryginalnej części archiwum politycznego Zygmunta Augusta znajdował się kodeks oprawiony w brązową skórę z superekslibrisem królewskim, a zawierający Livonica z roku 1556 i większość z 1557, a więc z czasu wyprawy pozwolskiej. Godny podkreślenia jest fakt książkowej dbałości w sporządzaniu kopiariusza, co trzeba złożyć na karb renesansowych zamiłowań kolekcjonerskich Zygmunta Augusta. Kodeks akt inflanckich z lat 1556-1557 mający oprawę królewską powstał jeszcze w latach pięćdziesiątych, nie ma jednak powodu wiązać go z pracownią Stanisława Górskiego (BJ 58). Inspiracją Tomicianów należy również tłumaczyć powstanie dwóch kolejnych ko-

\footnotetext{
64 W. Pociecha, dz. cyt., s. 27.

65 R. Marciniak, dz. cyt., s. 75, 92, 93.

66 Tamże, s. 32, 39-40, 104-105, 107.
} 
piariuszy Zygmunta Augusta ${ }^{67}$. Pierwszy z kodeksów zawiera korespondencję i akta dyplomatyczne z lat [1524] 1552-1558 [1562] z wyróżnieniem ślubu Zofii Jagiellonki i wyjazdu z kraju królowej Bony. Oprawiony został w brązową skórę z superekslibrisem i tytułem (BJ 175 t. I). Drugi kopiariusz, a trzeci w ogóle z oryginalnych Zygmunta Augusta, zawiera akta spraw węgierskich z lat 1552-1555. Oprawiono go w brązową skórę z superekslibrisem i tytułem „Rerum Transsilvanica” (BJ 175 t. II).

Godna podkreślenia jest dwutorowość rozwoju prywatnych archiwów politycznych w epoce Zygmunta Augusta. Charakterystyczne, że w większości przypadków archiwów z materiałami parlamentarnymi jesteśmy pewni bądź domyślamy się proweniencji małopolskiej. Archiwa polityczne dostarczają niejako potwierdzenia tezy o przodującej roli małopolskiej szlachty protestanckiej w ruchu egzekucyjnym. Istotne jednak, że nurt gromadzenia akt parlamentarnych, a precyzyjniej może nurt reprezentujący nastawienie na politykę wewnętrzną, niemal w ogóle nie mieszał się z nurtem drugim, niegubiącym z pola widzenia polityki zagranicznej. Nie można nurtu tego nazywać możnowładczym czy senatorskim. Najświetniejszym jego przedstawicielem był Stanisław Górski, skrzętnie przygotowujący dopiero narzędzie polityczne dla nowej generacji magnaterii, sam jednak skromny w gruncie rzeczy ekspisarz kancelarii mniejszej koronnej, w każdym razie profesjonalista znający mechanizmy gry politycznej od podszewki. Marcin Kromer do możnowładztwa też zaliczony być nie może. Trudno im za to odmówić dobrego przygotowania zawodowego do działalności politycznej. Można powiedzieć, że w tej grupie archiwalia polityczne gromadzą profesjonalni politycy wyrośli w długoletniej służbie Jagiellonów. W przyszłości te wszystkie kodeksy i akta luźne Stanisława Górskiego, Zygmunta Augusta i Marcina Kromera trafią do rąk nie działaczy szlacheckich, lecz przedstawicieli możnowładczych rodzin. Tak też, począwszy od pierwszego bezkrólewia, rozpocznie się nowy rozdział $\mathrm{w}$ dziejach gromadzenia i posługiwania się archiwaliami politycznymi w Polsce.

\section{Prywatne archiwa polityczne W CZASACH PIERWSZYCH KRÓLÓW ELEKCYJNYCH}

Zgony w tym samym roku Stanisława Górskiego i Zygmunta Augusta miały przełomowe wręcz znaczenie dla dziejów prywatnych archiwów politycznych w Polsce, nie mniej wielkie, choć niewspółmiernie różne z perspektywy ogólnohistorycznej. Bezkrólewie aktywizowało elity polityczne, popy-

${ }^{67}$ Tamże, s. 79-80. 
chało w wir walki o władzę, w której istotne miejsce już w dobie sejmów Zygmunta Augusta zajmowała dokumentacja aktowa. Odejście w roku 1572 dwóch wybitnych kolekcjonerów tekstów politycznych udostępniło ich dzieło elitom władzy. Tym razem jednak w dziedzinie gromadzenia archiwaliów politycznych prym mieli wieść mężowie stanu o orientacji senatorskiej lub wręcz możnowładcy, pierwsi z całej plejady twórców systemu klientarnego w Rzeczypospolitej albo też, jeśli ktoś woli, zwiastuni oligarchii magnackiej.

Jednym z tych, do rąk których trafiła spuścizna Stanisława Górskiego, był doświadczony i zasłużony już polityk Zygmunta Augusta Stanisław Karnkowski (1520-1603). Wskazujące senatorom, że to im należy się wiodąca rola w państwie, Tomiciana utrafiły dokładnie w gust przyszłego prymasa. Karnkowski już podczas bezkrólewi ujawnił wrodzoną sobie skłonność do autoreklamy połączoną z nie mniej stanowczym poglądem na rolę senatu. Witając Henryka Walezego na ziemi polskiej, Stanisław Karnkowski zdradził swoje zapatrywania polityczne, zgodnie z którymi naczelne miejsce należy się w państwie królowi w senacie przy lekceważeniu szlachty ${ }^{68}$.

Osobista kolekcja Tomicianów Stanisława Górskiego po jego śmierci w 1572 roku przeszła w ręce bratanka Piotra Tomickiego, kasztelana gnieźnieńskiego Jana, luteranina, na mocy testamentu Górskiego. Tomiciana te znajdowały się parę lat w rezydencji Tomickiego w Baranowie pod Kępnem. Wówczas to Jan i jego syn Andrzej, sędzia ziemski wieluński, podpisali się na kilku tomach. Wedle przypuszczenia Ryszarda Marciniaka po śmierci Jana Tomickiego 31 stycznia 1575 roku kolekcję odziedziczył jego najstarszy syn Mikołaj, prepozyt krakowski, ulubieniec kardynała Hozjusza. Od niego dopiero miałby uzyskać Tomiciana Stanisław Karnkowski. Zdaniem Marciniaka Karnkowski pozyskał Tomiciana przed uzyskaniem prymasostwa w roku 1581, znał je jednakże wcześniej, korzystając w czasie pierwszego bezkrólewia ze zwodu senatorskiego ${ }^{69}$. Zostały one oznaczone tuszową pieczątką własnościową Karnkowskiego z herbem Junosza.

Spośród Tomicianów Stanisława Karnkowskiego zachowały się do dziś: tom pierwszy za lata 1507-1511 jedynie w odpisie z XVIII wieku (B. Czart. 250), tom drugi za lata 1512-1513 (BK 219), tom trzeci za lata 1514-1515 (BJ 51), tom piąty za lata 1519-1521 (B. Oss. 176 II), tom siódmy za lata 1524-1525 (B. Oss. 177 II), tom dziesiąty za rok 1528 (BK 220), tom czternasty za lata 1532-1533 (B. Czart. 271 IV), tom siedemnasty za lata 1536-1537 (B. Oss. 6138 II; kopią z XVI wieku jest B. Oss. 178 II), tom dziewiętnasty za rok 1540 (B. Czart. 277), tom dwudziesty za rok 1541 (B. Oss. 179 II),

68 S. Grzybowski, Henryk Walezy, Wrocław i in. 1980, s. 107.

69 R. Marciniak, dz. cyt., s. 110-112. 
tom dwudziesty trzeci za lata 1545-1547 (B. Czart. 285), tom dwudziesty siódmy z korekturą Taszyckiego z roku 1532 i drukowanymi konstytucjami z roku 1538 (B. Czart. 269). Dochował się również do naszych czasów kodeks Karnkowskiego pochodzący z pracowni Stanisława Górskiego, zawierający dzieła Stanisława Orzechowskiego. Przeszedł on podobnie jak Tomiciana po śmierci Górskiego do Tomickich, a następnie do Stanisława Karnkowskiego (B. Czart. 2117 IV).

Stanisław Karnkowski, wszedłszy w posiadanie Actów Tomicianów (albo jeszcze wcześniej, podczas korzystania ze zwodu senatorskiego), sporządził ich kompendium, z myślą, jak wskazuje na to tytuł, ofiarowania królowi Stefanowi, z którym się związał i od którego wiele jeszcze miał zyskać. Kompendium stanowi jednocześnie pomoc informacyjną do Tomicianów, jak i dzieło samodzielne i należy przyjąć, że mimo złożenia go w darze królowi, a także, co nie dziwiłoby, szerszego rozpowszechnienia, Karnkowski zachował egzemplarz dla siebie. Kompendium 24 tomów chronologicznych Tomicianów autorstwa Stanisława Karnkowskiego zachowało się jednakże jedynie w kilku odpisach (Wojewódzka Biblioteka Publiczna w Kielcach, rps sygn. 8; BJ przyb. 22/52; B. Oss. 169). Usprawiedliwiony wydaje się domysł, że opracowanie i podarowanie Stefanowi Batoremu, kolejnemu obcokrajowcowi na tronie polskim, kompendium Tomicianów przez Stanisława Karnkowskiego było inspirowane ofiarowaniem Polonii Henrykowi. Można zaryzykować podejrzenie, że Karnkowski poprzez kompendium budował szczególnie wobec króla obraz siebie jako wartościowego źródła informacji o najnowszych dziejach narodu. Trafiał też w zainteresowania historyczne Batorego.

Znaczną rolę odegrały zapewne Tomiciana w koncepcji kopiariuszy korespondencji własnej Karnkowskiego, zarówno od niego wychodzącej, jak i przezeń otrzymywanej (B. Czart. $311 \mathrm{z}$ listami z lat 1565-1578; BPANKr. 1884 z listami z lat 1581-1593). Zdaniem Wincentego Zakrzewskiego to właśnie Tomiciana pobudziły Stanisława Karnkowskiego do zebrania własnej korespondencji i do ogłoszenia jej drukiem, co zgodne jest $\mathrm{z}$ jego naturą żądną sławy, a przeciwne całej postawie Górskiego ${ }^{70}$. Obok zbioru opublikowanego zachowało się kilka tomów rękopiśmiennych. W obszernym kodeksie zostały zebrane listy $\mathrm{z}$ lat 1565-1578 w układzie nieprzypadkowo hierarchicznym (B. Czart. 311 IV). Zebrał więc Karnkowski swoją korespondencję i pokazał ją odpowiednio uporządkowaną. W układzie można dostrzec przejrzystą koncepcję. Zbiór ogłaszał światu, jakie to znakomitości nie szczędziły trudu, by pisać do biskupa kujawskiego. Przyjrzyjmy się temu imponującemu

70 W. Zakrzewski, Stanistaw Górski i jego prace historyczne. Propozycja i zarys programu konkursu, Kraków 1909, s. 307. 
wykazowi: papieże Pius V i Grzegorz XIII, kardynałowie Stanisław Hozjusz, Jan Franciszek Commendone, wybitny, choć tylko biskup, Marcin Kromer, cesarz Maksymilian II, królowie Jan Zygmunt Zapolya, Zygmunt August, Henryk Walezy, Stefan Batory, Jan Waza, Anna Jagiellonka, udzielny władca Siedmiogrodu Krzysztof Batory, a po nim inni książęta, biskupi, między którymi da się znaleźć nazwisko Hieronima Rozrażewskiego, i wreszcie ludzie tak wybitni jak Piotr Skarga czy Stanisław Reszka. Nie powinno być chyba wątpliwości co do propagandowego wydźwięku takiej i tak uporządkowanej listy korespondentów. Oto Stanisław Karnkowski zdaje się przekonywać o swoich kwalifikacjach do objęcia w przyszłości, po naprawdę już niemłodym Jakubie Uchańskim, pierwszej godności w polskim Kościele, a jednocześnie pierwszego krzesła senatorskiego. Z dwoistego charakteru prymasostwa wynikło kościelno-państwowe grupowanie możnych korespondentów.

Godna podkreślenia jest przemyślana konstrukcja innego jeszcze kopiariusza korespondencji Stanisława Karnkowskiego (B. Oss. 154 II). Zawiera on najpierw listy Stanisława Hozjusza do Stanisława Karnkowskiego jako kanonika gnieźnieńskiego z lat 1555-1557, potem listy Hozjusza do Karnkowskiego jako kanonika gnieźnieńskiego i referendarza koronnego z lat 1558-1562, wreszcie listy Hozjusza do Karnkowskiego jako nominata biskupa włocławskiego z lat 1567-1569 i już jako biskupa włocławskiego w latach 1570-1573. Każda grupa jest wyraźnie oddzielona tytułem. Omawiany kopiariusz korespondencji ma przy tym charakterystyczną pieczątkę tuszową z Wieniawą. Z kodeksu emanuje nie tylko zażyłość z wybitnym księciem Kościoła, ale też wyczucie hierarchii i przekonanie o nieubłaganym wspinaniu się odbiorcy listów po jej szczeblach.

W innym kodeksie pomieszczono zarówno korespondencję prymasa Karnkowskiego z wielkimi tego świata z lat 1581-1593, jak i pomiędzy tymi dostojnikami (Biblioteka PAN i PAU w Krakowie, rps sygn. 1884). Śladu kodeksu Stanisława Karnkowskiego można doszukiwać się w rękopisie z XVII wieku zawierającym obok diariusza sejmu 1592 roku także zwartą grupę odpisów korespondencji Stanisława Karnkowskiego z lat 1587-1593 oraz innych akt charakteru publicznego wiążących się z osobą prymasa ${ }^{71}$. Pieczątką tuszową Stanisława Karnkowskiego został wreszcie opatrzony kopiariusz z aktami dotyczącymi stosunków polsko-śląskich, których oryginały były przechowywane w archiwum we Wrocławiu (B. Oss. 350 II). Przez większość kodeksu idą akta dotyczące spraw śląskich od roku 1337 do 1567, zebrane najwyraźniej

71 Diariusze i akta sejmowe r. 1591-1592, wyd. E. Barwiński, Kraków 1911, s. XVI-XVII. Rękopis znajdował się w Bibliotece Uniwersyteckiej we Wrocławiu i był, zdaniem Eugeniusza Barwińskiego, odpisem z tego samego zaginionego źródła co B. Czart. 2254. 
w ramach przygotowań do zjazdu we Wschowie w roku 1567, mającego uregulować kontakty sąsiedzkie polsko-śląskie, oraz akta samego zjazdu, następnie materiały rokowań bytomsko-będzińskich 1589 roku i wreszcie akta do ligi antytureckiej, też więc wiążące się z Habsburgami (w roku 1594 poseł cesarski przemawiał przed prymasem Karnkowskim).

Tomiciana uzyskane przez Stanisława Karnkowskiego stały się podstawą do dalszych odpisów. Najprawdopodobniej w latach osiemdziesiątych XVI wieku w Łowiczu kolekcja Tomicianów Karnkowskiego została skopiowana dla Hieronima Rozrażewskiego, zaufanego współpracownika pryma$\mathrm{sa}^{72}$, poza tym sekretarza wielkiego koronnego w latach 1574-1581, a następnie biskupa kujawskiego do śmierci w roku $1600^{73}$. Godne odnotowania jest, że Hieronim Rozrażewski jako proboszcz płocki jeździł do Francji, aby nakłonić Henryka do powrotu, a wierność jego dla Walezjusza przejawiała się wówczas w tym, że rozpowszechniał w Polsce kopie oficjalnych listów króla ${ }^{74}$. Prócz Tomicianów (AGAD, Archiwum Publiczne Potockich, sygn. 3; BN 9808; B. Czart. 257) trzeba wskazać inne archiwalia polityczne Rozrażewskiego lub jego bliskich krewnych. Zarówno on, jak i w ogóle członkowie jego rodziny odznaczali się wysokim poziomem kultury kancelaryjnej i archiwalnej. Znamy rękopis zawierający korespondencję braci Jana, Stanisława, Hieronima i Krzysztofa Rozrażewskich, kilka listów ich siostry Doroty, synowca Wacława i brata stryjecznego Jana (B. Czart. 331), a także kodeks z listami Hieronima Rozrażewskiego do różnych osób z lat 1578-1584, właściwie rejestr kancelaryjny jego korespondencji (B. Oss. 156/II).

W ostatnim dziesięcioleciu XVI wieku Tomiciana Rozrażewskiego odpisano na użytek prawdopodobnie innego bliskiego współpracownika prymasa, Jana Tarnowskiego herbu Rola, który później na mocy testamentu Karnkowskiego otrzymał i jego Tomiciana ${ }^{75}$. Jan Tarnowski, zmarły w 1605 roku, był kolejno sekretarzem królewskim, regentem kancelarii, referendarzem koronnym, podkanclerzym, towarzyszył Zygmuntowi III w podróży do Szwecji, wreszcie został biskupem poznańskim, biskupem kujawskim i arcybiskupem gnieźnieńskim ${ }^{76}$. Z osobą Jana Tarnowskiego Ryszard Marciniak łączy z pewną ostrożnością kilka istniejących do dziś kodeksów (BN 9809; B. Czart. 266, B. Czart. 270, B. Czart. 279, B. Czart. 286).

72 R. Marciniak, dz. cyt., s. 115.

73 Urzędnicy centralni i nadworni Polski, s. 146, 199.

74 R. Marciniak, dz. cyt., s. 114.

75 Tamże, s. 116.

76 K. Niesiecki, Herbarz polski, t. 9, Lipsk 1842, s. 50-51; Urzędnicy centralni i nadworni Polski, s. 110, 136, 209. 
Drugą osobą, której skarbnica tekstów politycznych niezmiernie zyskała na wydarzeniach 1572 roku wspomnianych na początku, był Andrzej Opaliński (1540-1593), kasztelan przemęcki od roku 1560, śremski od 1569, marszałek nadworny koronny od 1572, marszałek wielki od 1574, starosta generalny Wielkopolski od $1578^{77}$. Wśród materiałów politycznych Andrzeja Opalińskiego na pierwszym miejscu trzeba wymienić Tomiciana podarowane senatowi koronnemu, które być może już w 1567 roku znalazły się w kancelarii królewskiej. Po śmierci Zygmunta Augusta dołączyła do nich kolekcja królewska, co zapewne umożliwiło Andrzejowi Opalińskiemu jako marszałkowi nadwornemu w czasie pierwszego bezkrólewia przywłaszczenie pierwszego z kompletów ${ }^{78}$. Wśród zachowanych do dziś Tomicianów Andrzeja Opalińskiego należy wymienić: tom za lata 1506-1511 (BK 211), tom drugi za lata 1512-1513 (BK 212), tom dziewiąty za rok 1527 (BK 214), tom trzynasty za rok 1531 (BK 216), tom czternasty za lata 1532-1533 (BK 217), tom osiemnasty za lata 1538-1539 (BK 218), tom 26 zawierający listy Piotra Tomickiego (Biblioteka Zielińskich w Płocku, R-811).

Od Marcina Kromera przejął Andrzej Opaliński, choć w niewyjaśnionych okolicznościach, kopiariusz dokumentów Archiwum Koronnego Krakowskiego od XIII wieku do roku 1501, a następnie nadał mu typową dla swego archiwum oprawę z superekslibrisem (BK 203). Nie jest wykluczone, że jednocześnie w ręce Opalińskiego dostały się kopiariusze aktów pruskich oraz akt węgierskich z Archiwum Wawelskiego, których istnienie sugerują noty marginalne w omawianym kodeksie. Gdy Stefan Batory prosił Andrzeja Opalińskiego o wypożyczenie rękopisów dotyczących przeszłości Węgier ${ }^{79}$, miał na myśli być może kodeks węgierski wzięty od Kromera. Od Kromera Opaliński przejął również inny kodeks z odpisami dokumentów z Archiwum Koronnego Krakowskiego. Zgodnie ze swoim zwyczajem Opaliński wyposażył rękopis w piękną oprawę z brązowej skóry z superekslibrisem i dewizą „In Manu Dei Sortes Meae”, dziś zaginiony (BK 204).

W archiwum politycznym Andrzeja Opalińskiego starszego znajdował się ponadto kodeks zawierający akta sejmu warszawskiego 1563/1564 (BK 255), jak wskazuje na to typowa dla marszałka oprawa. Analiza znaków wodnych dowodzi, że kopia powstała pod sam koniec panowania Zygmunta Augusta, kiedy jednak weszła w skład archiwum Opalińskiego, z pewnością nie wiado-

77 W. Dworzaczek, Opaliński Andrzej (1540-1593), [w:] Polski stownik biograficz$n y$, t. 24, s. 72-78.

78 R. Marciniak, dz. cyt., s. 93.

79 K. Schuster, O kopiariuszach Andrzeja Opalińskiego marszatka wielkiego koronnego, Pamiętnik Biblioteki Kórnickiej, z. 7, 1959, s. 42. 
mo. Odcisk superekslibrisu wskazuje, że musiało to stać się przed połową lat osiemdziesiątych XVI wieku, wtedy bowiem oprawiono księgę wraz z paroma innymi kodeksami Opalińskiego ${ }^{80}$. Maniera estetyczna Opalińskiego, każąca mu przeprawiać jednolicie również kopiariusze mające już introligatorskie oprawy, nie pozwala na stwierdzenie, z jakiego źródła pozyskał marszałek omawianą jednostkę. Nie jest wykluczone, że odpis ten powstał bezpośrednio na jego zamówienie.

W drugiej połowie lat osiemdziesiątych XVI wieku, jak to wynika z analizy znaków wodnych, sporządzono również na zamówienie marszałka kopię kodeksu Liwoniców z lat 1556-1557 (BK 263) ${ }^{81}$.

Osobnego omówienia wymaga seria kopiariuszy oryginalnie powstałych na dworze Andrzeja Opalińskiego. Zainspirowany zwłaszcza posiadanymi Tomicianami Opaliński zapoczątkował tworzenie na ich wzór własnych kodeksów. Pierwszy kopiariusz obejmował materiały z roku 1578 (BK 279), drugi z zachowanych akta roku 1581 (BJ przyb. 186/51; BJ 999, BJ 3705). Kopiariusz z aktami roku 1582, choć zaginiony, został opisany w literaturze w stopniu, jaki pozwala na orientację w jego zawartości. Rękopis ten należał do Biblioteki Ordynacji Birżańskiej i nosił sygnaturę $1^{82}$. Składały się nań listy do Opalińskiego pisane przez Jana Piotrowskiego, w tym kontynuacja jego listów spod Pskowa, Jana Zamoyskiego i Stefana Batorego, oświetlające ważniejsze sprawy państwowe, wydarzenia dworskie czy z otoczenia kanclerza Zamoyskiego; dalej diariusze sejmiku średzkiego i generała kolskiego, a także diariusz sejmu 1582 roku $^{83}$. Do dziś istnieją oryginalne kopiariusze z lat 1583, 1585 i 1586 (BK 280, 281, 1708), a z roku 1588 jedynie w kopii z przełomu wieków XVI i XVII (B. Oss. 186). Kopiariusz z aktami roku 1585 został skopiowany w końcu XVI wieku, a w nieznanym bliżej czasie trafił do Archiwum Sanguszków (Archiwum Państwowe w Krakowie, Archiwum Sanguszków, sygn. 35). Kopiariusz Andrzeja Opalińskiego z roku 1585 zachował się również w odpisie z XVIII wieku (BN 6605). Istnienie kopiariuszy $\mathrm{z}$ lat następnych, po roku 1588, przynajmniej do roku 1590 lub nawet 1591, jest wysoce prawdopodobne. Związek wielu aktów z Andrzejem Opalińskim

${ }^{80}$ Katalog rękopisów staropolskich BK, t. 2, s. 465.

81 Tamże, s. 526. Kopiariusz, który otrzymał typową dla zbioru Andrzeja Opalińskiego oprawę, jest co prawda inną redakcją rękopisu BJ 58, nie stanowi jednak jego odpisu. Inną opinię wyraził Ryszard Marciniak, według którego po roku 1564 sporządzono w środowisku kancelarii królewskiej kopię akt liwońskich z kolekcji królewskiej być może od razu dla Andrzeja Opalińskiego (R. Marciniak, dz. cyt., s. 79).

82 Archiwum Jana Zamoyskiego, t. 3, wyd. J. Siemieński, Warszawa 1913, s. XXIII.

83 Tamże; J. Siemieński, Króla Stefana polityka sejmowa, Przegląd Historyczny, t. 34, 1937-1938, s. 44 i 47. 
starszym w ostatnich latach jego życia wykazuje np. kopiariusz akt politycznych z lat 1517-1609, stanowiący w XVIII wieku własność Michała Mycielskiego, a przechowywany dziś w Bibliotece Jagiellońskiej (BJ przyb. 2/52). Nie wydaje się, by powstawały kopiariusze przed rokiem 1578. Kamila Schuster uważa co prawda, że akta sejmu 1578 roku znajdowały się w pierwszej, zdefektowanej części rękopisu ${ }^{84}$. Najwięcej miejsca w kopiariuszach zajmuje korespondencja, najpierw przychodząca do marszałka Opalińskiego, z czasem również niezwiązana bezpośrednio z Opalińskim, a w końcu także wychodząca od Opalińskiego. Ważne miejsce zajmują też diariusze, których powstanie w niektórych przynajmniej wypadkach mógł inspirować Andrzej Opaliński: sejmów, uroczystości dworskich, rozmów Opalińskiego z Janem Zamoyskim ${ }^{85}$. Opaliński zdobywał materiały dzięki współpracy z oddanymi sobie informatorami, przebywającymi najczęściej na dworze królewskim lub w innym interesującym Opalińskiego miejscu: Wojciechem Baranowskim, Stanisławem Bojanowskim, Jakubem Brzeźnickim, Janem Gałczyńskim, Sebastianem Grabowieckim, Andrzejem Mierzewskim, swoim synem Piotrem Opalińskim, szczególnym przyjacielem Janem Piotrowskim, Janem Polickim, Stanisławem Przyjemskim, Janem Skrzetuskim i Stanisławem Sobockim ${ }^{86}$.

Około roku 1578 dla Andrzeja Górki została skopiowana kolekcja Tomicianów należąca do Andrzeja Opalińskiego. Dokładne określenie czasu sporządzenia odpisu Tomicianów dla Górki jest możliwe dzięki karteczce znajdującej się w tomie czternastym Tomicianów zwodu Opalińskiego, datowanej 15 marca 1578 roku, na której czytamy: „Incepi 14 Tomum Gorscii legere in Ossieczna Commentaria super 14 Tomum Responsum a Sigismundo primo Rege Poloniae” (BK 217). Ryszard Marciniak wypożyczenie Tomicianów przez Opalińskiego Andrzejowi Górce do Osiecznej tłumaczy zbliżeniem, jakie nastąpiło na fali sympatii dla Górki po jego uwięzieniu w końcu 1575 roku przez śląskiego barona Zygmunta Kurzbacha. Ten sam autor wysunął hipotezę, że Acta Tomiciana dla Górki przepisywał być może Leonard Gorecki, w którego kronice czasów Batorego zaczęły się pojawiać odpisy dokumentów, niewątpliwa inspiracja Tomicianów. Spośród Tomicianów Andrzeja Górki zachowały się: tom siódmy za lata 1524-1525 (BK 213), tom dziewiąty za rok 1527 (BK 215). Były to kodeksy oprawione w jasny pergamin $\mathrm{z}$ herbem Łodzia i literami ACG, przy czym zatarciu miałaby ulec lite-

${ }^{84}$ K. Schuster, dz. cyt., s. 47.

85 W. Chorążyczewski, Zbiór kopiariuszy Andrzeja Opalińskiego (1578-1588), [w:] Studia o bibliotekach i zbiorach polskich, t. 6, red. B. Ryszewski, Toruń 1994, s. 8-9, 18. 86 Tenże, Informatorzy Andrzeja Opalińskiego w latach 1578-1588, [w:] Studia o bibliotekach i zbiorach polskich, t. 7, red. B. Ryszewski, Toruń 1997, s. 11. 
ra A pomiędzy C i G, która z pozostałymi dawałaby się rozwiązać jako „Andreas Comes A Gorca" ${ }^{87}$. Były sporządzone starannie, z użyciem atramentu wysokiej jakości. Jak zaznaczono, skopiowanie Tomicianów na użytek Górki było możliwe, zanim Opaliński poróżnił się z Górkami. Początkiem złych stosunków było przegranie przez Górków starań o starostwo wielkopolskie. Jak czytamy w ówczesnym źródle, „było o to generalstwo wiele kłopotu, bo Stanisław grabia z Górki wojewoda poznański i Zborowski wojewoda krakowski starali się pilno na Jędrzeja grabię z Górki, kasztelana międzyrzeckiego [...] tak że kiedy mu [Stanisławowi Górce] Bekiesz ultimam voluntatem królewską powiedział, że je marszałkowi dać miał, tenere lacrimas non potuit" (BK 279, k. 1).

Andrzej Górka (ok. 1534-1583) był kasztelanem międzyrzeckim od roku 1570. Posłował na sejm 1567 roku z województwa poznańskiego. Aktywnie uczestniczył w pierwszym bezkrólewiu, kiedy posłował na konwokację. Wyrazem jego ówczesnej pozycji było wyznaczenie go do poselstwa jadącego do Francji po Henryka, jak i powierzenie mu na równi z biskupem Adamem Konarskim zadania informowania prymasa. Stawał się więc przywódcą różnowierców w poselstwie. Miał z bratem Stanisławem ogromny wpływ na szlachtę. Był aktywny podczas drugiego bezkrólewia. W roku 1578 ominęło go generalstwo wielkopolskie ${ }^{88}$.

Tworzenia kopiariuszy na wzór Tomicianów u Andrzeja Górki nie widać, mamy natomiast ślady całkiem przyzwoitego archiwum politycznego złożonego zapewne z materiałów luźnych. Najpierw trzeba zwrócić uwagę na diariusz poselstwa polskiego do Francji z roku 1573, który można znaleźć dziś w odpisach (BJ przyb. 74/52). Andrzej Górka jest autorem tego diariusza, co prawda nie sam jeden. Część tekstu dyktował, autorem zaś części był zaufany dworzanin Górków Henryk Giryk vel Girk. Diariusz powstał w celu ściśle utylitarnym i politycznym. Andrzej Górka prowadził urzędowy dziennik, mający prawdopodobnie służyć jako materiał do sprawozdania z misji złożonego przed stanami Rzeczypospolitej. Prowadzenie diariusza przez Górkę można tłumaczyć wypełnianiem obowiązku informowania prymasa o przebiegu poselstwa, nałożonego nań przez sejm elekcyjny ${ }^{89}$. Przypadek diariusza poselstwa do Francji wyprzedzający o kilka lat pozyskanie Tomicianów przez Górkę wskazuje, że był to polityk doceniający wagę dokumentacji pisanej

87 R. Marciniak, dz. cyt., s. 118-119, 211.

88 R. Żelewski, Górka Andrzej (ok. 1534-1583), [w:] Polski stownik biograficzny, t. 8, Wrocław i in. 1959-1960, s. 405-407.

89 Diariusz poselstwa polskiego do Francji po Henryka Walezego w 1573 roku, wyd. A. Przyboś, R. Żelewski, Wrocław i in. 1963, s. L-LIII. 
i dlatego kopiujący dla siebie Tomiciana, nie zaś kolekcjoner zainspirowany wspaniałością renesansowych kodeksów.

Z osobą Andrzeja Górki wiąże się też kronika czasów Stefana Batorego, zawierająca tak wiele akt wplecionych w narrację, co zresztą jest typowe dla epoki, że upodobniająca ją do kopiariusza akt politycznych. Kronika mogła więc spełniać analogiczną funkcję informacyjno-polityczną co kodeksy Andrzeja Opalińskiego, wielkopolskiego sąsiada Górki. Nie znamy niestety oryginalnego egzemplarza kroniki należącego do Górki, a jedynie nieco późniejsze odpisy (BK 278). Kronika lat 1575-1582 powstała w otoczeniu Andrzeja Górki i koncentrowała się na wydarzeniach politycznych. W formie jest diariuszem uzupełnionym aktami i korespondencją z archiwum Andrzeja Górki. Forma diariusza, i to wydarzeń politycznych w zasadzie, wobec autorstwa Górki diariusza poselstwa do Francji, każe się zastanowić, czy i tym razem udział Górki w powstawaniu dzieła nie wykroczył poza udostępnienie archiwaliów. Niewykluczone jest dyktowanie lub tylko udzielanie wskazówek co do zawartości treściowej, typowe dla mecenasów opiekujących się historykami. Niezależnie od stopnia udziału Andrzeja Górki w powstawaniu kroniki jej autorem był, jak wywiódł to Henryk Barycz, Leonard Gorecki. Prawdopodobnie zachowana do dziś w odpisie późniejszym kronika stanowiła część dziejów narodu polskiego od początków do czasów współczesnych pisarzowi. Henryk Barycz przypuszcza, że kronika nie była kontynuowana po roku 1582 z powodu choroby i śmierci Górki - mecenasa Goreckiego, co miało tegoż przybićc ${ }^{90}$. Wśród przytoczonych w kronice akt znajdujemy kopię listu Fogelwedera z Hiszpanii z roku 1578, którą król Stefan przedstawił senatorom, uniwersał królewski do senatorów i szlachty po zdobyciu Połocka w roku 1579, list króla do Górki, list Jana III króla szwedzkiego do króla polskiego, wreszcie list królowej szwedzkiej Katarzyny Jagiellonki do Stefana Batorego, wszystkie trzy z roku $1582^{91}$.

Archiwum polityczne Andrzeja Opalińskiego starszego zasiliło także materiałami warsztat pracy jego krewniaka Jana Opalińskiego (1546-1598), wychowanka Andrzeja Opalińskiego starszego, kasztelana rogozińskiego od roku 1578. Znamy co prawda jeden tylko kodeks, sporządzony najpewniej u Andrzeja Opalińskiego, oprawiony u tego samego introligatora co kodeksy Andrzeja, z materiałami z roku 1581 (BJ przyb. 186/51). Kopiariusz Jana Opalińskiego obok herbu na oprawie ma litery: I O C R, kryjące Jana Opalińskiego kasztelana rogozińskiego. Nie ma specjalnych przeciwwskazań, by

90 Kronika z czasów króla Stefana Batorego 1575-1582, wyd. H. Barycz, Kraków 1939, s. $4-15$.

91 Tamże, s. 56, 64, 83, 87, 88. 
domyślać się istnienia w epoce innych, zaginionych dziś, odpisów ze zbiorów rzutniejszego politycznie kuzyna. Domysł ten zdawał się podzielać Włodzimierz Dworzaczek, mówiąc, że Jan Opaliński, uchodzący za miłośnika książek, posiadał w swej siedzibie w Opalenicy obok między innymi kroniki bezkrólewia Świętosława Orzelskiego niektóre kopiariusze swego stryjeczno-stryjecznego brata Andrzeja ${ }^{92}$.

W sposób naturalny kodeksy marszałka Andrzeja Opalińskiego przeszły we władanie najpierw najstarszego syna Piotra Opalińskiego, a następnie, po śmierci jego w roku 1600, średniego, Andrzeja Opalińskiego młodszego. Piotr Opaliński (1566-1600), krajczy koronny od roku 1588, poseł na sejm 1592 roku, w spadku po ojcu otrzymał księgozbiór, a więc również interesujące nas kopiariusze akt politycznych. O tym, że czytał kopiariusze ojcowskie, można wnosić z pozostawionych przezeń zapisek marginalnych ${ }^{93}$, nie widać jednak, by dzieło ojca kontynuowat. W Piotrze można dostrzec co prawda pierwszego autora „Księgi rodowej Opalińskich”, kontynuowanej w następnych pokoleniach ${ }^{94}$.

Ciekawiej przedstawia się sprawa z bratem Piotra, Andrzejem Opalińskim młodszym (1576-1623), dworzaninem i sekretarzem królewskim, wielokrotnym posłem królewskim na sejmik średzki, dyplomatą, sekretarzem wielkim koronnym, wreszcie biskupem poznańskim od $1607 \mathrm{roku}^{95}$. Pracując jeszcze w kancelarii koronnej, sporządził on dla siebie kopie akt dotyczących koalicji antytureckiej, włączając je do księgi, której pierwszą część stanowią odpisy Tomicianów (Biblioteka Raczyńskich w Poznaniu, dalej cyt. B. Racz., rps sygn. 309). Kopiowanie Tomicianów wskazywałoby na powstanie kodeksu przed rokiem 1600, kiedy to Andrzej Opaliński młodszy uzyskał Tomiciana ojcowskie.

Wśród oryginalnej części archiwum politycznego Andrzeja Opalińskiego trzeba wymienić kodeks zbierający materiały generalnie z lat 1593-1608, choć zdarzają się pojedyncze akty z lat 1584 i 1589 (BK 306). Kopiariusz otrzymał oprawę wzorowaną na księgach ojca, a więc dewizę „In manu Dei sortes meae", superekslibris z wizerunkiem Łodzi i nieco tylko odmienne inicjały AOEP, co należy czytać: Andreas Opaliński Episcopus Posnaniensis. Wpisy są słabiej niż w kodeksach ojca oddzielone, a układ jednostki dość

92 W. Dworzaczek, Opaliński Jan (1546-1598), [w:] Polski stownik biograficzny, t. 24 , s. 81 .

93 R. Marciniak, dz. cyt., s. 203.

94 W. Dworzaczek, Opaliniski Piotr (1566-1600), [w:] Polski stownik biograficzny, t. 24, s. 100-101, wskazuje na Piotra Opalińskiego; R. Marciniak (dz. cyt., s. 145) na Jana.

${ }^{5}$ W. Dworzaczek, Opalinski Andrzej (1576-1623), [w:] Polski stownik biograficz$n y$, t. 24, s. $78-81$. 
chaotyczny. Kodeks zaczyna się niejako z chwilą śmierci Andrzeja Opalińskiego seniora, a więc w marcu 1593 roku, informując o zgonie tego wybitnego polityka. Sprawia to wrażenie świadomego niejako podjęcia przerwanego dzieła. Później następuje jednak przeskok chronologiczny i większość kopiariusza odnosi się do przełomu wieków XVI i XVII. Częste nawroty do aktów wcześniejszych i wymieszanie tematyczne obniżają wartość kodeksu. Zawartość treściowa nie wyczerpuje z całą pewnością wypadków ostatnich lat XVI i pierwszych XVII wieku, choć na wzór kopiariuszy ojca kodeks rejestruje zarówno zdarzenia europejskie (papiestwo, cesarstwo, Francja, Szwecja, najbliższe sąsiedztwo zachodnie Polski), jak i wewnątrzkrajowe (szczególnie Wielkopolska i dwór królewski). Andrzej Opaliński młodszy pozostawił po sobie inny jeszcze kopiariusz polityczny, należący już jednak do XVII wieku, zawierający głównie akta rokoszowe 1606-1607, ale też inne materiały z lat 1604-1615 (BK 1709).

W kręgu Wielkopolan powstał u samego progu epoki królów elekcyjnych co najmniej jeden jeszcze kodeks akt politycznych, niewiążący się z wyżej wymienionymi. Chodzi tu o kopiariusz Adama Konarskiego, dworzanina królewskiego od roku 1548, sekretarza królewskiego przynajmniej od 1551, od tego samego roku podkomorzego poznańskiego, dyplomaty Zygmunta Augusta, a wreszcie biskupa poznańskiego od roku 1562. Wybitną rolę odegrał Konarski podczas pierwszego bezkrólewia, gdy stał na czele poselstwa polskiego do Francji po Henryka Walezego ${ }^{96}$. Kopiariusz Konarskiego zbierał akta bezkrólewia po Zygmuncie Auguście (BN 9876). W Bibliotece Baworowskich we Lwowie znajdował się kodeks oprawny w skórę z tłoczonym herbem Habdank biskupa Adama Konarskiego i tytułem „Interregnum Anno Dom[ini] 1573”. Zawierał on sporo korespondencji Konarskiego oraz akt do bezkrólewia 1572-1574. Twórca kodeksu nie stronił przy tym od wierszy politycznych i broszur ${ }^{97}$. W literaturze zauważono jego podobieństwo ogólne do kodeksów Andrzeja Opalińskiego, a jednocześnie wskazano na pewne różnice. Dotyczą one, po pierwsze, mniejszej staranności wykonania. Po drugie, chodzi o przyjęcie innej koncepcji formowania kodeksu: zamiast konsekwentnego umieszczania akt jednego roku w osobnym kodeksie jak u Opalińskiego, u Konarskiego mamy akta od 3 lipca 1572 do 19 maja 1574 roku. Po trzecie, dopatrzono się różnic w źródłach pozyskiwania materiałów: Konarski nie

96 R. Żelewski, Konarski Adam (1526-1574), [w:] Polski stownik biograficzny, t. 13, Wrocław $\mathrm{i}$ in. 1967-1968, s. 447-449.

${ }_{77}$ Pisma polityczne z czasów pierwszego bezkrólewia, wyd. J. Czubek, Kraków 1906, s. VI-VII. 
posługiwał się informatorami przebywającymi na dworze królewskim, lecz ograniczał do wydarzeń, w których sam brał udział ${ }^{98}$.

Trzecią obok Stanisława Karnkowskiego i Andrzeja Opalińskiego osobą, której archiwum skorzystało na wydarzeniach 1572 roku, był Jan Zamoyski, późniejszy kanclerz i hetman wielki koronny. Już w marcu 1572 roku, po śmierci Stanisława Górskiego, Jan Zamoyski wszedł w posiadanie Tek Górskiego (BN, BOZ, Teki Górskiego, t. I-XXIX), które polecił przenieść do Zamchu. Ryszard Marciniak wyraził pogląd, że przejęcie Tek przez Zamoyskiego nie było przewidywane przez Górskiego. Miała to być osobista inicjatywa Zamoyskiego, ewentualnie na zasadzie rewindykacji materiałów publicznych ${ }^{99}$. W takim razie jednakże Zamoyski ponownie sprywatyzował Teki Górskiego. Zachowały się one w zbiorach rodzinnych aż do drugiej wojny światowej, po której trafiły do Biblioteki Narodowej (BN, BOZ, Teki Górskiego, t. I-XXIX). Fragment Tek Górskiego stanowi rękopis BJ 44 z odpisami z ksiąg poselskich z lat 1539-1541, 1544 i $1547^{100}$. Materiały z pracowni Stanisława Górskiego, a więc fragmenty Tomicianów, wymieszane z pismami oryginalnymi, ewentualnie z odpisami z późniejszych wieków, spotykamy dziś w wielu rękopisach (B. Czart. 254, 255, 262, 276, 281, 282, 283; BK 221, 222, 1461; AGAD, Zbiór Branickich z Suchej 22/32).

Nie było to jednak pierwsze zetknięcie się Zamoyskiego z dokumentacją polityczną. W naszym przeglądzie archiwaliów politycznych Jana Zamoyskiego nie może przecież zabraknąć inwentarza Archiwum Koronnego Krakowskiego zebranego w pięciu tomach (AGAD, AZ, sygn. 30, 31, 32, 33, 34). Działalność komisji porządkującej archiwum koronne pod koniec panowania Zygmunta Augusta jest faktem często przytaczanym w literaturze, choć nie doczekała się dotąd monografii. W skład komisji porządkującej archiwum koronne wchodzili Stanisław Górski, Szymon Ługowski i Jan Zamoyski. Należy domniemywać, że Stanisław Górski wnosił ogromne doświadczenie archiwalne, którym dzielił się z Zamoyskim, ten ostatni zaś, młodszy i silniejszy, wykonywał faktyczne prace porządkowe. Uporządkowane dokumenty, posygnowane, trafiły do specjalnie wykonanych szaf i szuflad. Dokumenty uzyskały układ według klucza geograficznego, przy czym akta nadające się do wielokrotnej klasyfikacji zostały zaopatrzone w odsyłacze. Powstał wówczas przejrzysty dla postronnych układ archiwum koronnego. Najwięcej pożytków przyniosło jednakże porządkowanie Zamoy-

${ }^{98}$ L. Kieniewicz, Projekt ordynacji kancelaryjnej za Henryka Walezego, Przegląd Historyczny, t. 78, 1987, z. 4, s. 714.

99 R. Marciniak, dz. cyt., s. 108-109, 182.

100 Tamże, s. 60. 
skiemu, który pilnie czytał dokumenty nawet po nocach. Przy okazji kazał sobie skopiować niektóre dyplomy, w sumie około 225 aktów. Pomawia się go nawet o przywłaszczenie niektórych dokumentów oryginalnych. Bruliony i czystopisy inwentarza zawierającego regesty około 3000 dokumentów pozostawił sobie Zamoyski do prywatnego użytku. Upominano się o nie w sierpniu 1572 roku na zjeździe w Knyszynie. Komisja wyznaczona przez sejm 1609 roku nie odnalazła również inwentarza sporządzonego przez Zamoyskiego i niektórych oryginałów ${ }^{101}$.

Istotne wydaje się, że podczas prac w archiwum koronnym Jan Zamoyski zetknął się ze Stanisławem Górskim. Następujące zaraz po tej pracy, a właściwie ją przerywające, bezkrólewie pozwoliło Zamoyskiemu zabłysnąć świeżo zdobytymi umiejętnościami. Dzięki porządkowaniu archiwum koronnego stał się on niezrównanym znawcą praw polskich ${ }^{102}$. Nieprzypadkowa jest zbieżność dat. Porządkowanie wypadło dokładnie u schyłku życia twórcy Act Tomicianów. Można się zastanawiać, czy gdyby nie kilkuletnia współpraca, Jan Zamoyski wszedłby w posiadanie Tek Górskiego, a więc matki licznych zwodów Tomicianów.

Po śmierci Mikołaja Sienickiego Jan Zamoyski przejął także po nim jego sylwę z odpisami aktów politycznych, wśród których należałoby się spodziewać bogatych materiałów parlamentarnych ${ }^{103}$.

Archiwum polityczne Jana Zamoyskiego, indywidualności skomplikowanej i nieschematycznej, zasługiwałoby na osobną rozprawę, zwłaszcza aspekt jego roli w działaniach podejmowanych przez kanclerza. Stanisław Grzybowski wyraził się o archiwum Jana Zamoyskiego, że było ono budowane „świadomie jako źródło ważnych informacji o współczesnych i jako własny pomnik dla potomnych" ${ }^{104}$. Archiwum to ma granice nie do końca przejrzyste. Szczególna uwaga należy się zachowanej w poważnych rozmiarach korespondencji Zamoyskiego ${ }^{105}$. Załącznikami do listów adresowanych do niego były na przykład lauda sejmików, które Eugeniusz Barwiński znajdował jesz-

101 S. Kutrzeba, dz. cyt., s. 366; A. Śliwiński, Jan Zamoyski kanclerz i hetman wielki koronny, Warszawa 1947, s. 37; S. Grzybowski, Jan Zamoyski, Warszawa 1994, s. 33-36; H. Michalak, Jan Zamoyski - propaganda i autoreklama, Przegląd Historyczny, t. 77, 1986, z. 1, s. 28.

102 W. Sobieski, Trybun ludu szlacheckiego. Pisma historyczne, Warszawa 1978, s. 146.

${ }^{103}$ R. Marciniak, dz. cyt., s. 110.

104 S. Grzybowski, Jan Zamoyski, s. 110.

105 W. Tygielski, Stronnictwo, które nie mogto przegrać, Przegląd Historyczny, t. 76, 1985, z. 2. Listy Zamoyskiego można odnaleźć przede wszystkim w Archiwum Głównym Akt Dawnych, w Archiwum Ordynacji Zamojskiej, sygn. 126-279, 635-639, 648-711, 756-871. 
cze w postaci luzów, później zaś współoprawne ${ }^{106}$. Przed sejmem 1592 roku, w który Jan Zamoyski był mocno zaangażowany, powstał nawet dla niego zbiorek uchwał szesnastu sejmików przedsejmowych ${ }^{107}$. Zamoyski prowadził korespondencję niezmiernie rozległą, odzwierciedlającą zarówno jego zainteresowania kulturalne, jak i działalność polityczną, wojskową i gospodarczą. $\mathrm{Na}$ rodaków wyjeżdżających za granicę nakładał niekiedy obowiązek przesyłania sprawozdań z krajów, po których podróżowali. Do niektórych centrów wysyłał zresztą swych własnych agentów. Korespondentów nie musiał daleko szukać. Był osobą na tyle znakomitą, że to o niego jako korespondenta zabiegano $^{108}$. Zamoyski przywiązywał do korespondencji wielką wagę, pozwalała ona bowiem na skuteczne uprawianie polityki. W czasach, gdy już odsunął się od dworu, orientację w sprawach państwowych ułatwiał mu fakt, że jego stronnicy byli zatrudnieni w kancelarii: Piotr Tylicki był podkanclerzym, Szymon Rudnicki regentem, referendarzem, potem sekretarzem wielkim, Piotr Ciekliński, Wawrzyniec Gembicki, Hieronim Godziątkowski byli zaś sekretarzami. W związku z tym Zamoyski wiedział o wszystkim, co przechodziło przez kancelarię. Korespondenci obecni w otoczeniu królewskim przesyłali mu relacje z informacjami o listach przychodzących do króla, o ich treści, sposobach załatwiania spraw, a czasem też kopie listów. Podobnie informowano kanclerza o pismach wychodzących z kancelarii. Interesów Zamoyskiego strzegli również Mikołaj Zebrzydowski jako marszałek wielki koronny i Jan Firlej jako podskarbi wielki koronny. Ten ostatni dostarczał informacji o stanie skarbu królewskiego, co stanowiło dla hetmana jedną z przesłanek podejmowania decyzji podczas prowadzonych działań wojennych. Korespondencja była wreszcie narzędziem propagandy (np. w celu przeciwdziałania fali krytyk w związku z wyprawą Tatarów w 1594 roku rozesłał szereg listów relacjonujących wypadki) ${ }^{109}$.

Drugą obok korespondencji grupą akt Zamoyskiego są liczne materiały, dla których dałoby się wskazać miejsce w archiwum koronnym czy Metryce Koronnej ${ }^{110}$, brudnopisy kancelarii koronnej przejęte przez kanclerza, luźne polityczne akta oryginalne, a wreszcie akta urzędu hetmańskiego Jana Zamoyskiego (AGAD, AOZ, sygn. 35, 36, 37), wszystko dziś trudne do rozdzie-

106 Por. Diariusze sejmowe r. 1597, wyd. E. Barwiński, Kraków 1907, s. XXIV.

107 Diariusze i akta sejmowe r. 1591-1592, s. XIV-XV.

108 Archiwum Jana Zamoyskiego, kanclerza i hetmana wielkiego koronnego, t. 4: 1585-1588, wyd. K. Lepszy, Kraków 1948, s. V-VI.

109 V. Urbaniak, Zamoyszczycy bez Zamoyskiego. Studium dekompozycji ugrupowania politycznego, Warszawa 1995, s. 20-21, 58.

110 Por. T. Zielińska, Zbiory archiwalne ordynatów Zamoyskich jako skarbnica dokumentów pañstwowości polskiej, Miscellanea Historico-Archivistica, t. 4, 1994, s. 173-221. 
lenia ze względu na osobowość kanclerza. Wydaje się, że Zamoyski miał do swych akt stosunek czysto użytkowy i nie przywiązywał najmniejszej wagi do ich estetyki. Porównajmy tylko wspaniałe kodeksy Zygmunta Augusta czy Andrzeja Opalińskiego z tą górą luzów i składek Zamoyskiego. Całe szczęście zresztą, że czasem mamy do czynienia ze składkami, które, choć do dziś nieoprawne, zachowały jednak postać gotowych materiałów do kopiariusza.

W związku z funkcjami państwowymi Zamoyskiego trzeba wymienić księgę z aktami polskiej polityki zagranicznej (księgę poselską, która zamiast do Metryki Koronnej trafiła do prywatnego archiwum pieczętarza?) od 25 lutego 1577 do 23 lutego 1578 roku, a więc z czasu podkanclerstwa Zamoyskiego (AGAD, AOZ, sygn. 3041).

Kolejna zachowana jednostka zbiera akta rokowań polsko-moskiewskich prowadzonych po wyprawie pskowskiej Batorego osobiście przez kanclerza (AGAD, AOZ, sygn. 280). Kopiariusz ten wykazuje duże podobieństwo treści do kodeksu Andrzeja Opalińskiego z materiałami z roku 1581 (BJ przyb. 186/51). Analizę porównawczą odnośnych kopiariuszy Jana Zamoyskiego i Andrzeja Opalińskiego przeprowadził Józef Siemieński, który doszedł do następujących wniosków: kodeks Zamoyskiego ma charakter urzędowy, pozostałe zaś, wszystkie będące odpisami kopiariusza Opalińskiego, prywatny; kodeks Zamoyskiego prowadzony od 7 grudnia 1581 roku do 9 marca 1582 roku stanowi źródło wszystkich tekstów księgi Opalińskiego w podanym wyżej zakresie chronologicznym, w tym samym również układzie, przy czym odpisy kodeksu Opalińskiego są nieco uboższe w teksty; kopiarz Zamoyskiego jest oryginalnym kopiarzem obozowym, z którego Jan Piotrowski czerpał odpisy wysyłane Andrzejowi Opalińskiemu ${ }^{111}$. Ostatnia z odnośnych jednostek to kopiariusz akt politycznych związanych ze sprawowaniem urzędu kanclerskiego z lat 1600-1602 (AGAD, AZ 281).

W niektórych przypadkach prywatny charakter archiwaliów politycznych jest bardziej oczywisty, utylitarne jednak nastawienie Zamoyskiego, koncentrującego się na praktycznej przydatności informacji zawartych w aktach, znów komplikuje sprawę. W obliczu sejmu 1605 roku Jan Zamoyski zainteresował się rokoszem lwowskim z czasów Zygmunta Starego. Zatrudnił przy tym jednak swego teścia Stanisława Tarnowskiego, kasztelana sandomierskiego, by czuwał nad gromadzeniem odnośnych materiałów ${ }^{112}$. Do czyjego archiwum weszły zebrane dokumenty?

Podobnie jak Stanisław Karnkowski i Andrzej Opaliński inspirowali narastanie archiwów politycznych w swym otoczeniu, tak też dokumentację

111 Archiwum Jana Zamoyskiego, t. 2, wyd. J. Siemieński, Warszawa 1909, s. VI-VIII.

112 V. Urbaniak, dz. cyt., s. 26. 
polityczną gromadził nie tylko sam Zamoyski, ale też jego stronnicy na czele z Mikołajem Zebrzydowskim (zm. 1620), wojewodą lubelskim od roku 1589, marszałkiem wielkim koronnym od 1596, wojewodą krakowskim od $1601^{113}$. W końcu XVI wieku narastało archiwum luźnych materiałów wiązane z osobą Zebrzydowskiego. W jednej z jednostek oprawiono razem materiały z lat generalnie 1588-1590, wśród nich zaś oryginalne listy adresowane do Zebrzydowskiego; poza tym najwięcej akt dotyczyło spraw sejmikowych. Znajdują się tutaj także aż dwa diariusze sejmu 1585 roku (B. Czart. 1621). Z Mikołajem Zebrzydowskim należy wiązać również rękopisy z materiałami lat 1590-1591 (B. Czart. 1620). Eugeniuszowi Barwińskiemu nie udało się odnaleźć trzeciego z rękopisów Zebrzydowskiego, o którego istnieniu wnioskował z napisów na okładkach istniejących kodeksów, drugiego według tych oznaczeń. Z lat 1591-1597 pochodzi ostatni rękopis z aktami Mikołaja Zebrzydowskiego, a zawierający oryginały, koncepty z odręcznymi poprawkami Zebrzydowskiego lub wreszcie kopie akt publicznych i listów (B. Czart. 2724).

Pod koniec XVI i na początku XVII wieku narastało, być może, archiwum Stanisława Tarnowskiego, teścia Jana Zamoyskiego. Przed sejmem 1605 roku Zamoyski zainteresował się rokoszem lwowskim z roku 1537. Przy gromadzeniu materiałów zatrudnił wówczas - jak już wspomniano - Tarnowskiego ${ }^{114}$. Jest to zatem dowód na to, że Zamoyski przymuszał niemal swych stronników do stylu pracy politycznej posiłkującej się archiwaliami.

W końcu XVI wieku powstał kodeks zawierający diariusz poselstwa do Francji po Henryka Walezego, dokumenty z lat 1573-1575, opis Wenecji z roku 1589, diariusz sejmu 1585 roku i różne zboroviana. Istnieje domysł, że kopiariusz powstał w otoczeniu braci Zborowskich. Zaczęto go tworzyć zaraz po powrocie z poselstwa do Francji. Początkowo miał zbierać materiały do stosunków zagranicznych, ostatecznie jednak jego posiadacz skoncentrował się na sprawach wewnętrznych po konflikcie Zamoyskiego ze Zbo-

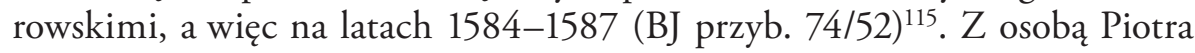
Zborowskiego można wiązać zbiór odpisanych dokumentów, listów i relacji związanych z elekcją Henryka Walezego 1572-1573 (BN III 3083). Podpisy Piotra Zborowskiego i zestaw dokumentów świadczą o jego prowenien-

113 Urzędnicy województwa lubelskiego XVI-XVIII wieku. Spisy, oprac. W. Kłaczewski, W. Urban, red. A. Gąsiorowski, Kórnik 1991, s. 57, 133; Urzędnicy centralni i nadworni Polski, s. 80, 218; Urzędnicy województwa krakowskiego, s. 108, 275.

114 V. Urbaniak, dz. cyt., s. 26.

115 Por. Diariusze sejmowe r. 1585, wyd. A. Czuczyński, Kraków 1901, s. XI-XII; Diariusz poselstwa polskiego, s. XLII-XLIII. 
cji. Na marginesach znajdują się dopiski jedną ręką, być może także Piotra Zborowskiego.

Kopiariusz wiązany z osobą wojewody krakowskiego od roku 1581, przedtem kasztelana i wojewody bełskiego ${ }^{116}$, Andrzeja Tęczyńskiego, zaczyna się od listu Stefana Batorego z 6 października 1586 roku do wojewody zwołującego sejm na początek następnego roku, ostatni zaś wpis datuje się na wrzesień 1589 roku. Większość materiałów pochodzi jednakże z końca 1586 i pierwszej połowy 1587 roku (AGAD, Archiwum Publiczne Potockich, sygn. 6) ${ }^{117}$. W literaturze nie zwrócono jednak uwagi na fakt, że Andrzej Tęczyński zmarł 22 maja 1588 roku $^{118}$, część zatem kodeksu nie mogła z całą pewnością pochodzić od wojewody krakowskiego, a od spadkobierców kopiariusza.

Z kolei Jan Sienieński, kolejno kasztelan żarnowski, lwowski i wreszcie wojewoda podolski od roku $1588^{119}$, był twórcą rękopisu z materiałami lat 1587-1595, zawierającymi oryginały i kopie akt urzędowych i korespondencji (B. Czart. 2723).

W końcu wieku XVI można zaobserwować geograficzny rozwój zjawiska prywatnych archiwów politycznych. Ze znacznym rozmachem wkroczyły one w tym czasie na Litwę. Wśród twórców inspirowanych przez Tomiciana należy tu wymienić Lwa Sapiehę (zm. 1633). Byłby to zresztą czwarty dygnitarz Rzeczypospolitej obok Karnkowskiego, Opalińskiego i Zamoyskiego, który uzyskał zbiór akt z pracowni Stanisława Górskiego. Wiemy bowiem na pewno, że kolekcja senatu litewskiego znajdowała się w ręku Sapiehów, synów kanclerza Lwa, w pierwszej połowie XVII wieku. Zapewne przywłaszczył ją sobie Sapieha w latach osiemdziesiątych XVI wieku. Najodpowiedniejszym momentem wydaje się przejmowanie akt kancelarii litewskiej, wśród których należy domyślać się miejsca przechowywania kolekcji senatu litewskiego, po śmierci Ostafieja Wołłowicza w grudniu 1587 roku. Kolekcja uległa zatracie podczas drugiej wojny światowej, jeszcze we wrześniu 1939 roku, gdy przewieziono ją z Rogalina do Warszawy ${ }^{120}$. Dysponujemy dziś jedynie dwoma tomami wypisów z Tomicianów zwodu Lwa Sapiehy,

116 Urzędnicy województwa krakowskiego, s. 107, 266; Urzędnicy województwa betskiego i ziemi chetmskiej XIV-XVIII wieku. Spisy, oprac. H. Gmiterek, R. Szczygieł, red. A. Gąsiorowski, Kórnik 1992, s. 33, 71.

117 Por. W. Semkowicz, Przewodnik po zbiorze rękopisów wilanowskich, Warszawa 1961, nr 6, s. 29-30; J. Dzięgielewski, W. Sokołowski, Bonis czy rebus - nowe materiaty i propozycje interpretacji aktu konfederacji warszawskiej z 1573 r., Kwartalnik Historyczny, t. 92,1985 , z. 2, s. 299-315.

118 Urzędnicy województwa krakowskiego, s. 107.

119 K. Niesiecki, Herbarz polski, t. 8, s. 358-359.

120 R. Marciniak, dz. cyt., s. 93, 123, 190, 199. 
powstałymi po śmierci tegoż, dla jednego z dwóch synów Lwa, Jana Stanisława lub Kazimierza Lwa (BK 223; B. Czart. 264). Kodeksy powstały zapewne zaraz po śmierci Lwa Sapiehy, a za życia Jana Stanisława Sapiehy (zm. 1635). Wówczas synowie Lwa, Jan Stanisław i Kazimierz Lew, mogli przejąć Tomiciana ojcowskie. Dla jednego wykonano więc skrót zwodu. Jan Stanisław zmarł bezpotomnie i wówczas obydwa komplety trafiły do biblioteki Kazimierza Lwa w Różanie.

Niewiele wiemy o innych archiwaliach politycznych Lwa Sapiehy. W archiwum różańskim Sapiehów miało się znajdować sprawozdanie (diariusz) z poselstwa Lwa Sapiehy do wielkiego księcia Borysa Godunowa z lat 1600-1601, napisane przez sekretarza legacji Eliasza Pielgrzymowskiego ${ }^{121}$. Godna uwagi jest też korespondencja Lwa Sapiehy, wśród którego korespondentów możemy wymienić króla Zygmunta III, szczególnie zaś jego deliberatoria, Annę Jagiellonkę, dostojników Rzeczypospolitej ze Stanisławem Karnkowskim, Janem Zamoyskim, Piotrem Tylickim, Janem Dymitrem Solikowskim, Janem Karolem Chodkiewiczem ${ }^{122}$.

Tomiciana podarowane senatowi litewskiemu wykorzystał w końcu XVI wieku Krzysztof Zenowicz, wojewoda brzeski litewski, tworząc swój własny kodeks tekstów politycznych. Kodeks Krzysztofa Zenowicza zawierał przede wszystkim wypisy z Tomicianów, uzupełnione aktami zbieranymi przez samego Zenowicza na przełomie XVI i XVII wieku (1511-1554, 1597-1607). Te ostatnie są już jednak niestaranne, bez porządku, wyrywkowe, świadczące o braku dostępu do cennych materiałów (AGAD, Zbiór Branickich z Suchej, sygn. 39/53).

Szukając litewskich archiwów politycznych XVI wieku, koniecznie trzeba zajrzeć do niezmiernie bogatego archiwum nieświeskiego Radziwiłłów, dziś zwanego Archiwum Warszawskim Radziwiłłów (dalej cyt. AWR) i przechowywanego w Archiwum Głównym Akt Dawnych. Ma ono w swym zasobie całą masę luźnych archiwaliów politycznych, w tym również z XVI wieku. Należy zwrócić uwagę na dział II, najzasobniejszy w interesujące nas materiały. Znajdziemy tu między innymi liczne akta do sprawy Zborowskich w latach 1584-1586 (AGAD, AWR, dz. II, sygn. 129, 131, 134, 135, 136, 137, 145, 149, 152), do bezkrólewia roku 1587 (AGAD, AWR, dz. II, sygn. m.in. $159,197,210,211)$ czy do pierwszych lat panowania Zygmunta III (AGAD, AWR, dz. II, por. sygn. 197, 232, 245a, 247, 254, 261, 264, 265, 266, 267,

121 Archiwum domu Sapiehów, t. 1: Listy z lat 1575-1606, oprac. A. Prochaska, Lwów 1892, s. XV; Poselstwo Lwa Sapiehy w roku 1600 do Moskwy podtug diariusza Eliasza Pielgrzymowskiego sekretarza poselstwa, Grodno 1846.

${ }^{122}$ Archiwum domu Sapiehów, s. XXIII-XXIV. 
269, 270, 273, 317, 318, 320, 386). Co charakterystyczne, wiele odpisów wiąże się z osobą Jana Zamoyskiego, które ilustrując działania polityczne kanclerza, nie są jego korespondencją z Radziwiłłami. Z ostatniej przesłanki można wysnuć podejrzenie, że Radziwiłłowie pozyskiwali aktywnie materiały polityczne od kanclerza koronnego. Analiza not dorsalnych (regestów, ewentualnych sygnatur) nie potwierdza wyodrębniania się archiwaliów politycznych, nie jest też pewne, czy spora część materiałów nie znajdowała się w XVI wieku w ręku innym niż Radziwiłłowskie. Znaczenie dla naszych rozważań ma korespondencja oryginalna Radziwiłłów. Należy wspomnieć przynajmniej o listach przedstawicieli domów panujących (dział III), listach pisanych przez Radziwiłłów (dział IV) i listach rodzin obcych (dział V), a wreszcie o zbiorze gazetek pisanych, wśród których znajdują się nowiny z zagranicy z lat $1594-$ -1595 (dział XXXIV). Charakterystycznym problemem jest kwestia, czy do Radziwiłłów w XVI wieku należał zbiorek mów z sejmu elekcyjnego 1573 roku (AGAD, AWR, dz. II, sygn. 90), czy też może trafił on do Nieświeża w wyniku późniejszego zbieractwa.

$\mathrm{Na}$ wyróżnienie zasługuje syn Mikołaja Radziwiłła „Czarnego”, Jerzy Radziwiłł (1556-1600), biskup wileński, gubernator Inflant w latach 1582-1584, kardynał, biskup krakowski, w późniejszych latach zwolennik ligi antytureckiej, choć rozsądny, nie chciał bowiem, by Rzeczpospolita znalazła się sama wobec potęgi osmańskiej ${ }^{123}$. Ze sprawowaniem funkcji namiestnika Inflant należy wiązać zainteresowanie się sprawami tego kraju. Polityczność kodeksu akt inflanckich, pisanego ręką Jerzego Radziwiłła, zasadniczo z lat 1560-1572, choć obejmujących wyjątkowo lata 1422-1592 (B. Czart. 2180), nie ulega wątpliwości. Kopiariusz ten odznacza się zresztą pewną interesującą cechą, akta mianowicie są w nim połączone narracją historyczną, przechodzącą dla lat, dla których brakuje akt, w swego rodzaju kroniczkę historii inflanckiej. Gorzej ma się rzecz z innym kodeksem, zbierającym głównie listy od roku 1583 oraz inne akta, jak dekrety czy przywileje związane ze zwalczaniem herezji w Europie (AGAD, AWR, dz. V, sygn. 92). W tym samym kopiariuszu można jednak znaleźć niewątpliwe materiały polityczne dotyczące układów bytomsko-będzińskich czy legację posła Zygmunta księcia siedmiogrodzkiego do Zygmunta III Wazy.

Ciekawie przedstawia się także postać brata kardynała Jerzego Radziwiłła, Mikołaja Krzysztofa Radziwiłła „Sierotki” (zm. 1616), marszałka nadwornego i marszałka wielkiego litewskiego, kasztelana i wojewody trockiego, wresz-

123 W. Müller, Radziwitt Jerzy (1556-1600), [w:] Polski stownik biograficzny, t. 30, Wrocław i in. 1987, s. 229-234. 
cie wojewody wileńskiego ${ }^{124}$. Interesujących danych dostarczył rejestr przychodów i wydatków „Sierotki” za rok 1571. Wśród wielu cennych zapisów świadczących o funkcjonowaniu kancelarii przybocznej (kupowanie papieru, sznurków, wosku) znajdujemy tam pozycję: „Za Pargamin, aby porządek na niem spissano Panow iako w radzie zaszadaią z roskazania JE[go] M.”125 $\mathrm{Z}$ późniejszych lat dysponujemy ciekawie brzmiącą instrukcją Radziwiłła „Sierotki” dla synów z roku 1603, z której przytoczymy fragmenty: „Pisma, sprawy, listy potrzebne, abyście pilno chowali, aby nie latali po cudzych rękach [...] czytajcie je, abyście wiedzieli, i tym sobie zabawkę czynili, a do experientij przychodzili: stoi to za wielką naukę takie rzeczy wiedzieć, a zwłaszcza w sprawach, które i przodkowie waszy sprawowali" ${ }^{126}$. W testamencie Mikołaja Krzysztofa Radziwiłła „Sierotki” czytamy z kolei:

także pierścień na Cardynalstwo z szafirem i dwa sygnety jego [kardynała Jerzego Radziwiłła, brata „Sierotki” - przyp. W. Ch.], których acz używać nie może [syn najstarszy „Sierotki” - przyp. W. Ch.], ale aby z drugiemi rzeczami po nim było, to w domu moim i z tą skrzynką, którą mi zapisał testamentem, gdzie odprawa jego jest wszytka i inne rzeczy, kiedy go Ojciec Święty posyłał legatum a latere, tedy te pierścienie i szkatuła z sprawami wiecznie w Nieświeżu ma bydź. Niech potomstwo baczy i cieszy się z tego, że i obcym Monarchom służył pobożnie przodek ich ${ }^{127}$.

Nie znamy więc co prawda oryginalnych materiałów zgromadzonych przez „Sierotkę”, wiemy za to, że dziedziczył po Jerzym, a być może też po swoim ojcu Pretomiciana. O ile oczywiście to jeszcze Mikołaj „Czarny” nie zaprzepaścił ich dla rodziny. Ryszard Marciniak wysunął domysł, że Pretomiciana Mikołaja Radziwiłła „Czarnego”, po śmierci tegoż niedoceniane przez spadkobierców, uległy rozproszeniu ${ }^{128}$. Tymczasem to, co wiemy o kulturze archiwalnej jego synów, wspomnianego już Jerzego i Mikołaja Krzysztofa „Sierotki”, przeczy tej tezie.

Niewiele znamy z ostatniej ćwierci XVI wieku archiwów politycznych ewidentnie szlacheckich. Najjaskrawszy i w dawnym już stylu jest przypadek archiwum Stanisława Taszyckiego, syna szlacheckiego przywódcy Mikołaja, który zresztą silniej od syna zapisał się w polskiej historii. Stanisław wyrósł na

124 Urzędnicy centralni i dygnitarze Wielkiego Księstwa Litewskiego XIV-XVIII wieku. Spisy, oprac. H. Lulewicz, A. Rachuba, Kórnik 1994, s. 73, 77, 234.

125 Vilniaus Universiteto Biblioteka, F5-B67-3408, k. 21v.

126 Z dokumentów Xięcia Mikotaja Krzysztofa Radziwitta zwanego Sierotka, Warszawa 1905 , s. 46.

127 Tamże, s. 76.

128 R. Marciniak, dz. cyt., s. 122. 
jednego z czołowych działaczy średnioszlacheckich w województwie krakowskim w drugiej połowie XVI wieku. W literaturze doczekał się pochlebnej opinii za swą aktywność, światłość, patriotyzm, pobożność (co prawda ariańską), dbałość o praworządność. W latach 1573-1587 co najmniej pięciokrotnie posłował na sejmy z krakowskiego, kilkakrotnie też bywał deputowanym w celu załatwiania różnych spraw ${ }^{129}$. Stanisław Taszycki, w przeciwieństwie do ojca, upamiętnił się zbiorkiem tekstów politycznych do dziś zachowanym, z lat 1571-1596 (BJ 1101). Przy okazji można się zastanowić, oczywiście zakładając, że Mikołaj Taszycki nie pozostawił podobnego kodeksu, nie zaś, że taki zaginął, czy Stanisław nie żył po prostu w bardziej sprzyjających podobnemu zbieractwu czasach, w atmosferze częściej podejmowanych analogicznych inicjatyw, w warunkach większego uaktowienia kultury politycznej.

$\mathrm{Na}$ rękopis Stanisława Taszyckiego, z którego zachował się do naszych czasów fragment, składają się mowy (m.in. Zygmunta III do arcyksięcia Maksymiliana w Krasnymstawie 2 maja 1589 roku czy też Stanisława Taszyckiego do króla Stefana), listy polityczne (w tym Stanisława Taszyckiego) i pisma polemiczne z czasów Batorego i pierwszych pięciu lat panowania Zygmunta Wazy. Kodeks był kontynuowany przez synów Stanisława. Ci jednakże, dość liczni, bardziej musieli myśleć o utrzymaniu pozycji społecznej rodziny niż o polityce. Stąd też z tych czasów pochodzą zapisy gospodarcze i prywatne, z których szczególnie cenne są noty kronikarskie. Fragmenty polityczne wyróżniają się nie tylko treściowo, ale także formalnie (pismo), co pozwala przyjąć, że to nie synowie Stanisława Taszyckiego zebrali jego materiały polityczne, lecz on sam. Jeśliby traktować kopiariusz Stanisława Taszyckiego jak typowe archiwum polityczne średnioszlacheckiego polityka, to trzeba by wyróżnić trzy przynajmniej jego cechy: selektywny zestaw materiałów niedający pełnego obrazu współczesności, spory udział materiałów politycznych własnego autorstwa twórcy archiwum, co z kolei decyduje o lepszym obrazowaniu jego działalności publicznej, wreszcie większy, niż we wielkich archiwach politycznych, udział tekstów publicystycznych.

Do domysłów skłania zaobserwowany przypadek pozyskiwania relacji o sejmie 1585 roku. Fragmentaryczny diariusz tego sejmu przesłał mianowicie swemu przyjacielowi Budzińskiemu jeden z posłów, Radoszowski, w liście z 6 lutego 1585 roku. Mówi się tam o tym, co działo się na sejmie dzień po dniu od początku do momentu wysłania listu (B. Oss. 200). O jakiego

129 W. Urban, Kroniczka rodziny Taszyckich z końca XVI w., Odrodzenie i Reformacja w Polsce, t. 13, 1968, s. 208. 
Budzińskiego chodzi, trudno powiedzieć. Bartosz Paprocki znał rodzinę Budzyńskich herbu Dąbrowa, „w makowskim powiecie dom rozrodzony” ${ }^{30}$.

Wiemy też z pewnością, że niejaki Łaziński był posiadaczem zbiorku konstytucji sejmów 1539, 1540 i 1543 roku, na którego wolnej karcie podpisał się w sposób następujący: „Generozvs Dominus Łazinski. Anno domini 1583” (BK 903). Nota znajduje się w sąsiedztwie tekstów absolutnie niepolitycznych, jak łacińska wersja modlitwy Ojcze nasz, co świadczy o tym, że Łaziński, posiadając zbiorek w czasach Batorego, przynajmniej go otwierał, skoro znalazł wolną kartę na własne uzupełnienia. Zbiorek konstytucji przerodził się w swoistą książeczkę do nabożeństwa. Podobnie jak Budzińskiego (vel Budzyńskiego), trudno jest zidentyfikować Łazińskiego albo też Łazieńskiego - rodzinę o tym nazwisku herbu Jastrzębiec, mieszkającą w powiecie drohickim, zna współczesny wpisowi Łazińskiego Bartosz Paprocki131. Ślad występowania materiałów politycznych u mało znanych przedstawicieli stanu szlacheckiego wydaje się bardzo znamienny. Dowodzi on raz jeszcze, że zjawisko prywatnych archiwów politycznych miało zasięg dużo większy, niż to wynika z zachowanej do dziś spuścizny. Każe traktować zachowane archiwa w pewnym sensie jako przykłady podobnych całości aktowych, losowo nam przekazane.

Trudna do określenia jest proweniencja kopiariusza akt politycznych z lat 1562-1575, a zasadniczo z lat 1572-1575. Obok materiałów z wymienionych wyżej lat włączono doń akta z roku 1605. Wreszcie z tak powstałym kopiariuszem współoprawiono akta luźne z końca XVI i początku XVII wieku (BJ przyb. 60/52). Proweniencja jednostki też nie jest oczywista. Na pochodzenie z archiwum Mikołaja Dłuskiego mogłoby wskazywać umieszczenie rączki i liter NB przy jego legacji z roku 1572, co nabiera pewnego znaczenia, gdy zauważy się znaczny udział akt małopolskich w kopiarzu. $\mathrm{Na}$ oprawie wytłoczono wprawdzie herb Leliwa, którego Dłuscy nie używali, ale mogło tu też chodzić o proweniencję późniejszą. Mikołaj Dłuski był posłem sejmowym i działaczem reformacyjnym. Szerszą działalność polityczną rozwinął podczas pierwszego bezkrólewia. Brał wówczas udział w sejmie konwokacyjnym i podpisał konfederację warszawską. Aktywnie uczestniczył również w drugiej elekcji. Od października 1580 do maja 1581 roku sprawował funkcję starosty surogata krakowskiego. W latach 1560-1571 prowadził dziennik na kartach efemeryd wydanych w Wenecji w 1557 roku. Pozostawił sporą bibliotekę, której egzemplarze zaopatrywał w superekslibrisy ${ }^{132}$.

130 B. Paprocki, Herby rycerstwa polskiego, Kraków 1858, s. 415.

131 Tamże, s. 184.

132 H. Barycz, Dtuski Mikotaj, [w:] Polski stownik biograficzny, t. 5, Kraków 1939-1946 , s. $195-197$. 
Podsumowując rozważania, trzeba stwierdzić, że po roku 1572 ton wśród twórców archiwów politycznych nadają magnaci koronni i litewscy, i to z pierwszych rodów senatorskich. Archiwa działaczy średnioszlacheckich, nieliczne i ubogie, co prawda nie znikają zupełnie, stają się jednak trudne w ogóle do identyfikacji. Rozwój dotyczył wyłącznie skarbnic dokumentowych tworzonych przez magnatów. To oni mieli środki i możliwości niezbędne do tworzenia prawdziwie cennych archiwów politycznych. Tak jak w poprzednim okresie w archiwaliach politycznych odbijał się dynamizm ruchu egzekucyjnego, tak teraz z ich rozwojem najlepiej koresponduje budowa systemu patronatu i klienteli lub też tradycyjnie ujmowanej magnackiej oligarchii, zależnie od punktu widzenia.

\section{WYKORZYSTANIE ARCHIWALIÓW POLITYCZNYCH}

Rzadko dysponujemy wyznaniami samych twórców prywatnych archiwów politycznych na temat korzystania przez nich z posiadanych rękopisów. Wyjątkiem jest chyba tylko Stanisław Karnkowski, który wydając swą korespondencję, napisał, jak wiele zawdzięczał lekturze Tomicianów, mianowicie, że stosował wyniesione z nich nauki podczas bezkrólewi po Zygmuncie Auguście i Henryku Walezym ${ }^{133}$. Ryszard Marciniak domyśla się, iż Tomiciana były pomocne Stanisławowi Karnkowskiemu również podczas przygotowywania dzieła De republica regni Poloniae libri quinque, z którego ukończył tylko pierwszą księgę ${ }^{134}$.

Świadectwem czytania akt politycznych są oczywiście marginalia dowodzące nieraz żywej reakcji i pobudzenia aktywności intelektualnej. Niestety, już Ryszard Marciniak zwrócił uwagę na fakt, że kosztowne rękopisy, starannie przechowywane, nie zachęcały do wpisywania na marginesy własnych uwag przez czytelnika ${ }^{135}$.

Mimo to znajdujemy niekiedy w kopiariuszach akt politycznych przykłady żywego reagowania czytelników w postaci uwag marginalnych. Świadczą one najpierw w ogóle o korzystaniu z jednostki, co jest przecież rzeczą ulotną i najczęściej niepozostawiającą wyraźnego śladu, poza tym jednak mogą wskazywać na cel, w jakim kodeks wykorzystywano. Tak jest z diariuszem sejmu lubelskiego 1569 roku, którego czytelnik należał z pewnością do jednego z działaczy egzekucyjnych z województwa krakowskiego. Użytkownik z XVI wieku, czytając uchwały sejmiku proszowickiego poprzedzającego

133 W. Zakrzewski, dz. cyt., s. 290.

134 R. Marciniak, dz. cyt., s. 113.

135 Tamże, s. 19. 
sejm, nie powstrzymał się przed zapisywaniem z boku nurtujących go myśli. Jedna z not jest niezmiernie interesująca. Przy fragmencie uchwał „aby na potym seymiki powiathowe, dlusszi czas myaly, a namniey steri dni przed Nowomieiskim seymem, a steri niedzieli przed walnym” zauważył: „Dobre seymiki Nowomieyskie y trzeba aby beły consnstitucią opatrzone y reassumowane" (BK 258, k. 11). Przez słowa te przebija troska szlacheckiego działacza, który żyjąc w kulturze uznającej dawne prawa i urządzenia za lepsze, znajdował $\mathrm{w}$ aktach uzasadnienie dla instytucji sejmiku generalnego województw małopolskich w Nowym Mieście Korczynie. Czytelnik wyśmienicie zapewne czuł, jeśli nawet sobie tego nie uzmysławiał, jakie znaczenie dla urabiania się opinii szlacheckiej i organizacji politycznej stanu szlacheckiego mają dysputy na sejmikach generalnych, jak bardzo wpływają na siłę i spójność izby poselskiej.

W Tomicianach Andrzeja Górki z lat 1524-1525 znajdujemy także interesujące marginalia stanowiące nie tylko dowód czytania, ale też komentarz polityczny, jak „Niewola sliaheczka” przy uchwale „Contributio generalis [...]” (BK 213, s. 286), czy przy innym wpisie, gdzie w nawiązaniu do słów o sytuacji na Węgrzech przed Mohaczem znajduje się rączka z notą „, $[\mathrm{t}] \mathrm{ak}$ w Polscze wlasznie" (BK 213, s. 444). Czy niezgoda i rozbicie społeczeństwa węgierskiego przed klęską żywo przypomniały czytelnikowi realia polskie po wymarciu dynastii jagiellońskiej i zrodziły obawy co do dalszych losów ojczyzny?

Za sam dowód korzystania $\mathrm{z}$ akt politycznych należy uznać fakt kontynuacji gromadzenia materiałów politycznych inspirowany posiadanymi archiwaliami. Można to odnieść do obydwu Andrzejów Opalińskich, ojca i syna, Andrzeja Górki, Stanisława Karnkowskiego. Świetnym przykładem może być Andrzej Opaliński młodszy, który w roku 1600 przejął po swym bracie archiwum ich ojca Andrzeja Opalińskiego seniora. Wtedy, a być może nawet jeszcze za życia brata, zbierał on materiały do własnych kopiariuszy akt politycznych. Ciekawą przesłanką jest też rozpoczęcie kodeksu od listu pisanego w tydzień po śmierci Andrzeja Opalińskiego seniora i o niej informującego, co sprawia wrażenie świadomego niejako podjęcia przerwanego dzieła (BK 306, k. 68).

Gdy zastanawiamy się nad rolą archiwaliów w praktyce politycznej ruchu średniej szlachty, nie wolno zapominać, że czołowy działacz szlachecki, Mikołaj Sienicki, był mistrzem politycznym najwybitniejszego polskiego męża stanu końca XVI wieku, Jana Zamoyskiego. Doświadczenie starego egzekucjonisty było z pewnością tylko jedną z przesłanek szerokiego wykorzystywania akt przez Zamoyskiego, obok inspiracji Tomicianami i osobistych predyspozycji, jakże jednak wiele mówiącą o atmosferze życia publicznego ówczesnej Polski. Fakt terminowania u boku Sienickiego wychodził u Za- 
moyskiego na jaw może najbardziej w sposobie posługiwania się argumentami prawno-politycznymi. Stanisław Grzybowski pomysł powołania się na rokosz rycerstwa ruskiego z roku 1436, z którym wystąpił Zamoyski, przypisał Mikołajowi Sienickiemu ${ }^{136}$.

W historiografii panuje zgodny pogląd, że uporządkowanie archiwum koronnego przez Jana Zamoyskiego było w jego życiu wydarzeniem niezmiernej wagi, zwłaszcza że dało mu do ręki wiedzę, z której czerpał argumenty w walce politycznej ${ }^{137}$. Następujące zaraz po tej pracy, a właściwie ją przerywające, bezkrólewie pozwoliło Zamoyskiemu zabłysnąć świeżo zdobytymi umiejętnościami. Dzięki porządkowaniu archiwum koronnego stał się on niezrównanym znawcą praw polskich. Sam Zamoyski uważał się zresztą jedynie za tłumacza starych praw, podobnie zresztą jak inni działacze szlacheccy XVI wieku. Nie mieli oni poczucia tworzenia czegoś nowego, a jedynie wykonywania prac rekonstrukcyjnych ${ }^{138}$.

Pierwsze wystąpienie Jana Zamoyskiego podczas bezkrólewia po Zygmuncie Auguście było jednakże nieudane i trochę szkolarskie. Powołując się na dokument z XV wieku, z czasu, gdy ziemia bełska należała do książąt mazowieckich, a starosta bełski pełnił funkcję wychowawcy czy opiekuna dzieci książęcych, on, jako aktualny starosta bełski, postanowił zwołać sejmik z pominięciem lokalnych senatorów. Uderzał tym samym w kasztelana Andrzeja Tęczyńskiego, który jednak potrafił odeprzeć atak szlacheckiego przywódcy ${ }^{139}$.

Następne powołanie się Zamoyskiego na dawne prawa odcisnęło już jednak wyraźne piętno na dziejach Polski. Pracując mianowicie nad tekstem aktu konfederacji województwa bełskiego, zinterpretował dokument szlachty ruskiej z roku $1436 \mathrm{w}$ taki sposób, że wynikała stąd zasada elekcji viritim jako obowiązek szlachecki. Akt konfederacji z 10 lipca 1436 roku dotyczył województw ruskiego, podolskiego i bełskiego. Zamoyski zregestował go już podczas prac w archiwum koronnym, a także przetłumaczył. Teraz ujawnił go szlachcie zebranej na sejmiku ziemi chełmskiej w Krasnymstawie. Uchwała sejmiku powołała się na ów akt „rokoszu”, godząc się na interpretację Zamoyskiego. Według niej z zagrożenia karami w akcie z 1436 roku tym, którzy nie wezmą udziału w zjazdach ziemskich, wynikał obowiązek przymusowego stawienia się wszystkich obywateli na elekcji. Nie miało znaczenia, że w akcie

136 S. Grzybowski, Mikotaj Sienicki, s. 111.

137 S. Herbst, Początki historycznego ujmowania rzeczywistości w nauce i sztuce polskiego Odrodzenia, Warszawa 1953, s. 377.

138 W. Sobieski, dz. cyt., s. 146.

139 Tamże, s. 74; S. Grzybowski, Jan Zamoyski, s. 39-40. 
konfederacji z 1436 roku mówiło się o sejmikach ziemskich, a nie o sejmie ${ }^{140}$. Wystąpienie Zamoyskiego i uchwała szlachty chełmskiej odegrały ogromną rolę w ukształtowaniu się koncepcji elekcji viritim, choć Zamoyski nie był jej jedynym zwolennikiem ani też nie zwyciężyła wersja przymusowego udziału w elekcji. Ostatnio co prawda próbuje się nieco wyważyć problem wkładu Zamoyskiego w konfederację ziemi chełmskiej ${ }^{141}$. O instrumentalnym traktowaniu spuścizny prawnej przeszłych wieków świadczy fakt, że Zamoyski znalazł historyczno-prawne podstawy wolnej elekcji w momencie, gdy porzucił pogląd o elekcji poprzez reprezentantów szlachty.

Zamoyski w najbliższych latach nie rezygnował z wykorzystywania akt politycznych w działalności publicznej. Posiłkując się starymi wzorami, układał dekret elekcji króla Henryka. Służył senatorom informacją o przymierzach zagranicznych Polski. Artykuł de non praestanda oboedientia wysnuł z przywileju Aleksandra Jagiellończyka z roku 1501. Miał zawsze pod ręką kopie dokumentów z archiwum koronnego. Zabierał je w podróże, między innymi do Paryża, uczestnicząc w poselstwie po Henryka Walezego. Tu dzięki swemu warsztatowi układał pisma w imieniu poselstwa. Nic dziwnego, że zyskał sobie w tym czasie opinię niezastąpionego w sprawach publicznych ${ }^{142}$.

Za panowania Stefana Batorego Jan Zamoyski współpracował z Reinholdem Heidensteinem przy pisaniu komentarzy o wojnach moskiewskich. Zamoyski uważał się w ogóle za ich głównego twórcę, nie tylko zresztą komentarzy, ale też dziejów Polski lat 1583 i 1584, które weszły później do Historii Polski Heidensteina. Heidenstein w rozumieniu Zamoyskiego byłby jedynie pomocnikiem czy sekretarzem. Korespondencja między Heidensteinem a Zamoyskim dowodzi, że obaj współpracowali wciąż nad dziejami polskimi w roku 1593, kiedy Heidenstein pisał też samodzielnie. Współpraca autorska miałaby mieć miejsce zimą 1593/1594 podczas pobytu Heidensteina w Zamościu. W roku 1599 Heidenstein pracował sam nad dziejami ojczystymi, ale obiecywał przywieźć kanclerzowi rękopis do odczytania lub poprawy. Rola Zamoyskiego polegała zwłaszcza na dostarczaniu materiałów źródłowych i dzieł pomocniczych. Można przyjąć, że Zamoyski podawał Heidensteinowi szkic tekstu, najistotniejsze fakty oraz ich oświetlenie, właściwy tekst opracowywał jednak sam Heidenstein, dysponując materiałami uzyskanymi od kancle$\mathrm{rza}^{143}$. Zamoyski pośrednio wykorzystał więc swoje archiwum publiczne do

140 W. Sobieski, dz. cyt., s. 93-99.

141 S. Grzybowski, Jan Zamoyski, s. 40-41.

${ }_{142}$ H. Michalak, dz. cyt., s. 28; S. Łempicki, Śladem komentarzy Cezara, [w:] tenże, Mecenat wielkiego kanclerza. Studia o Janie Zamoyskim, Warszawa 1980, s. 86-387.

143 S. Łempicki, dz. cyt., s. 387-401. 
prac historycznych, wysługując się jednakże w szczegółach Reinholdem Heidensteinem. Jako dawca informacji i interpretacji faktów, a ponadto dostarczyciel źródeł kontrolujący ostateczny kształt dzieła, uważał się za właściwego autora. Nie da się wykluczyć, że w niektórych okresach, zwłaszcza we wcześniejszych, współpraca Heidensteina z Zamoyskim rzeczywiście usprawiedliwiała tezę o współautorstwie.

Jednocześnie codzienna praca z aktami weszła u Zamoyskiego w zwyczaj. Gromadził materiały dotyczące sprawy Zborowskich w roku 1584, najpewniej w celu „udokumentowania oparcia własnego stanowiska o szeroką aprobatę opinii publicznej"144. Jak już była mowa, przed sejmem inkwizycyjnym 1592 roku powstał na użytek Jana Zamoyskiego zbiór uchwał szesnastu sejmików przedsejmowych, którego cel tak wyjaśnia Eugeniusz Barwiński: „był niewątpliwie umyślnie sporządzony dla kanclerza Jana Zamoyskiego, który, w sprawach sejmu inkwizycyjnego wybitnie zaangażowany, według chodzących wieści na ten sejm gotował zamach stanu i starał się w przededniu sejmowej batalii poznać przyszłe szanse i horoskopy z rezultatów sejmikowych" ${ }^{145}$. Jeszcze dowodnie raz, w obliczu sejmu 1605 roku, Jan Zamoyski sięgnął do archiwaliów politycznych. Zainteresował się wówczas rokoszem lwowskim z czasów Zygmunta Starego. Zatrudnił przy tym swego teścia Stanisława Tarnowskiego, kasztelana sandomierskiego, by czuwał nad gromadzeniem odnośnych materiałów ${ }^{146}$.

Jak widać, Jan Zamoyski, genialny interpretator dawnych rozwiązań, znajdujący zawsze $\mathrm{w}$ archiwaliach uzasadnienie dla swych posunięć, sięgał do akt w zależności od bieżących potrzeb politycznych. Czynił tak do końca swego życia. Właściwie całej jego działalności publicznej towarzyszył nawyk obcowania $\mathrm{z}$ archiwaliami. I do samego końca nie można było przewidzieć, na jakie materiały każą mu zwrócić uwagę zaistniałe okoliczności. Mimo dysponowania najpokaźniejszym chyba w państwie zasobem tekstów politycznych, skarbnicę tę wciąż należało rozwijać ze względu na te właśnie nieprzewidywalne wyzwania chwili.

Zupełnie inna osobowość przebija z archiwum Stanisława Karnkowskiego, też przecież wybitnego męża swej epoki, polityka i myśliciela politycznego. Nadawanie rozgłosu swym poczynaniom publicznym zdawało się od zawsze leżeć w naturze Stanisława Karnkowskiego. Daje temu świadectwo

144 Z. Kolankowski, Zapomniany prawnik XVI wieku Jan Eaczyński i jego „Kompendium sądów króla jegomości”. Studium z dziejów polskiej literatury prawniczej, Toruń 1960, s. 17.

145 Diariusze i akta sejmowe r. 1591-1592, s. XV.

146 V. Urbaniak, Zamoyszczycy bez Zamoyskiego, s. 26. 
Marcin Kromer w swej Polonii, pisząc w związku z komisjami gdańską i elbląską dla „naprawienia pewnych błędów i nadużyć”: „ten, co przewodniczył owemu poselstwu, mąż znakomity, Stanisław Karnkowski, biskup kujawski, ogłosił te prawa drukiem"147. Przy okazji wypada zauważyć, jak wielkim uznaniem Karnkowskiego musiało cieszyć się dziełko biskupa warmińskiego o Rzeczypospolitej, w którym on sam ukazuje się w tak pochlebnym świetle. Wszystko, co wiemy o przyszłym prymasie, każe uznać go za człowieka dbałego o autoreklamę. Nic dziwnego, że zajął się Kromerowską Polonią. Nakłonił bowiem Marcina Kromera do ofiarowania tego dzieła królowi-elektowi Henrykowi, które to w rękopisie przekazał Walezjuszowi, ze względu na zajęcia warmińskie autora, sam Karnkowski przy wjeździe Henryka do Rzeczypospolitej. Dzieło nie tylko miało pouczyć nowego króla o stosunkach krajowych w sposób odpowiadający zapatrywaniom obozu senatorskiego, ale też pomóc w pozyskaniu łask monarchy ${ }^{148}$.

Działając wciąż w tym samym duchu, w roku 1574 Karnkowski wydał, zawierający teksty dokumentów, tom De iure provinciali terrarum maiorumque civitatum Prussiae, mający zaznajomić Henryka z problematyką morską. Korzystał wówczas z materiałów dotyczących Gdańska, zebranych przez instygatora koronnego Michała Friedwalda do użytku komisji królewskiej działającej od roku $1568^{149}$.

Klasycznym przykładem spożytkowania archiwum politycznego w celach promowania własnej osoby są zwłaszcza działania Stanisława Karnkowskiego w pierwszej połowie panowania Stefana Batorego. Zauważono w literaturze rolę wydanego drukiem zbioru listów wówczas jeszcze biskupa kujawskiego we wsparciu jego starań o prymasostwo. Obejmujący lata 1567-1578, miał on spełniać funkcję autoreklamującą w dużo wyższym stopniu niż kompendium. Taki właśnie cel publikowanego zbioru listów był już dostrzegany w literaturze i nie ma powodu zmieniać tego ustalenia. Nie widać po prostu innego celu, jaki stałby przed ambitnym Karnkowskim w końcu lat siedemdziesiątych XVI wieku, niż przekonanie współczesnych, że jest on najlepszym kandydatem do godności prymasowskiej. Celowi temu służył oczywiście nie tylko sam fakt wymiany listów z wielkimi tego świata, ale także to, co się w nich pisało. $Z$ treści korespondencji wynikają jasno usługi oddane Kościołowi i krajowi przez biskupa kujawskiego ${ }^{150}$. Raz jeszcze dowodziły

${ }_{147}$ M. Kromer, Polska, s. 193.

148 R. Marchwiński, Wstęp, [w:] M. Kromer, Polska, s. XX-XXII; M. Kromer, Polska, s. 4 .

${ }^{149}$ R. Marciniak, dz. cyt., s. 113.

150 Por. H. Kowalska, Karnkowski Stanistaw (1520-1603), [w:] Polski stownik biograficzny, t. 12, Wrocław i in. 1966-1967, s. 78. 
one jego kwalifikacji do kierowania polskim Kościołem. Ostatecznie Karnkowski osiadł na stolicy gnieźnieńskiej. Czy można z tego wyciągać wniosek, że umożliwiły mu to zabiegi czynione w oparciu o posiadane archiwum polityczne? Na pewno jakoś pomogły, stanowiły jednak jeden zaledwie z czynników wynikłych w czasie długotrwałych starań. Wyważenie proporcji poszczególnych czynników byłoby zadaniem ryzykownym. W każdym razie Stanisław Karnkowski naprawdę oryginalnie podszedł do problemu spożytkowania archiwum politycznego.

Dowodu na profesjonalne wykorzystanie archiwum politycznego dostarczył wreszcie jeden z kopiariuszy marszałka koronnego Andrzeja Opalińskiego. Przygotowując się do rokowań pokojowych z posłami habsburskimi, będąc komisarzem Rzeczypospolitej obok Jana Zamoyskiego i Hieronima Rozrażewskiego, marszałek sporządził sumariusz dokumentów oświetlających na przestrzeni dwóch poprzedzających wieków stosunki Polski z krajami habsburskimi, a więc Austrią, Węgrami, Czechami i Śląskiem, które posiadał w kopiach. Dokument zatytułowany Puncta niektóre Pana Marszałka Koronnego do Commissiej barzo potrzebne będace miał na celu ukazanie paktów, jakie Polska zawierała z Austrią, Czechami i Węgrami. We wstępie Opaliński zdradził pochodzenie swej wiedzy i styl pracy: „Porządkiem przeto patrzmy jakie Pacta są i co w sobie zamykają. Ja mniemam, że tego więcej w skarbie jest ale to co u mnie jest tedy krótce przypominam”. Potrafił następnie wyliczyć dla stosunków polsko-austriackich: układ króla Kazimierza z arcyksięciem Albertem z roku 1462, tegoż Kazimierza z cesarzem Fryderykiem $\mathrm{z}$ roku 1470, układ między tymiż skierowany przeciw Maciejowi węgierskiemu z roku 1474, wreszcie Zygmunta Augusta z cesarzem Karolem i królem Ferdynandem z roku 1549. Drugą grupę dokumentów otwiera nota: „Dalej zasię patrzmy w Pacta Czeskie i Śląskie które były z Koroną”. Do grupy tej wchodziły: układ Jana Luksemburczyka z Kazimierzem Wielkim z roku 1337, tychże królów z roku 1339, Wacława IV z Władysławem Jagiełłą z roku 1395, Ferdynanda Habsburga z Zygmuntem Starym z roku 1538, tegoż Ferdynanda z Zygmuntem Augustem z roku 1549. Po tym wyliczeniu zaznaczono, że „czego wszystkiego istorum Pactorum et Faederum była executio, bo przeciwko występnym były składane sejmy". Opaliński znał trzy zjazdy polsko-habsburskie w sprawach sąsiedzkich polsko-śląskich, od roku 1531 do 1567. Wreszcie przeszedł do paktów węgierskich, z których wyliczył układ między Ludwikiem Węgierskim a Kazimierzem z roku 1369 oraz akty z lat 1400, 1412, 1439, 1440, 1474, 1492, 1499, 1507 (B. Oss. 186, s. 282-289).

Prywatne archiwum polityczne dostarczyło tym samym kompetentnie materiału do działania na forum publicznym. Przypadek Opalińskiego, być może wcale niewyjątkowy, świadczy o celu, jaki przyświecał nowożytnym 
warsztatom aktowym w ręku nowoczesnych, a więc coraz bardziej zawodowych, polityków.

Spuścizna poprzednich pokoleń stanowiła dla polityków XVI wieku skarbnicę wzorców i rozwiązań wymagających tylko dopasowania do współczesności. Ze skarbnicy tej korzystano wybiórczo, rezygnując z przypominania zwyczajów i praw niewygodnych, nadając zaś niekiedy walor precedensu aktom nieoczekiwanym, zyskującym nagle nową wagę, a w zmienionych warunkach politycznych praktycznie też nową treść. Jedno jest pewne: hołdowanie w życiu politycznym zasadzie prymatu dawnego prawa wymagało odpowiedniej znajomości tekstów tego prawa, pozwalało także pretendować znawcom i objaśniaczom dawnych praw do roli przywódców politycznych. Stosowanie zasady interpretacji sprzyjało zainteresowaniu się dawnymi ustawami i wzorcami zachowań zapisanymi w aktach. Akta stały się nieodłącznym składnikiem polskiej kultury politycznej XVI wieku, a ich gromadzenie stawało się koniecznością dla polityka chcącego odgrywać wybitniejszą rolę w życiu publicznym. Można wręcz dostrzec prawidłowość, że im większą rolę chce się odgrywać, w tym szerszym zakresie należy korzystać z archiwaliów i tym więcej gromadzić akt. Cechą archiwum politycznego wydaje się przy tym pozostawanie znacznej części jego zasobu w stanie spoczynku, który przerywa dopiero zewnętrzna konieczność i wola użytkownika decydującego się na spożytkowanie tego, a nie innego pasującego do sytuacji tekstu.

\section{Private political archives in Poland of the XVI century}

Summary

"Private political archives" are understood by me as all acts collected intently by a private person. These acts are connected with the person's participation in political life and gathered in order to be used in public activity as the source of argumentation and information about factors and mechanisms of political processes. Private political archives of the first half of the XVI century were mainly created by royal servants, often with reference to their job duties. These duties could inspire to collect political acts for private purposes. During the reign of Sigismund Augustus, archives of gentry activists were developed to small extent and they mainly focused on parliamentary life. Private political archives were created outside the executionist movement, namely in the community gathered around the royal court. After 1572, Crown and Lithuanian magnates greatly influenced the creation of political archives.

Archives of lesser gentry, scarce and poor, did not disappear completely. However, they became difficult for identification. Therefore, developmental process concerned exclusively documentary "treasure troves" created by magnates. They had the financial means and possibilities to create truly valuable political archives. The same as in the pre- 


\section{8

vious period the dynamisms of executionist movement was reflected in political archival documentation, now the creation of patronage system and clientele, or traditionally understood magnate oligarchy (depending on the point of view) corresponded best to archives development. The heritage of previous generations was the treasure trove of patterns and solutions. However, this trove was used selectively, on one hand giving up patterns and rights that were uncomfortable, and, on the other, giving the value of precedence to unexpected acts that gained more importance or even new content in changed political conditions. The application of interpretation principle raised interest in old acts and patterns of behaviour described in acts. Consequently, they became an inseparable part of Polish political culture of the XVI century, and their collection became indispensable for any politician trying to play a more significant role in public life. It is easy to see some kind of regularity - the bigger role to be played, the bigger scope of archival materials to be used and collected. However, it was characteristic for political archives that their main part was not used until some external necessity and the user's will raised in order to exploit one specific text corresponding to one specific situation. 